\title{
The influence of changes in flow regime caused by dam closure on channel planform evolution: insights from flume experiments
}

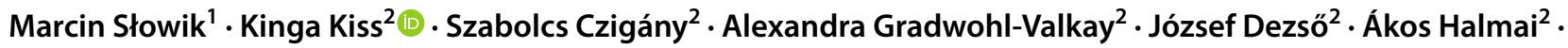 \\ Adam Marciniak ${ }^{1} \cdot$ Remigiusz $^{\text {Tritt }}{ }^{1} \cdot$ Ervin Pirkhoffer $^{2}$
}

Received: 19 February 2020 / Accepted: 20 January 2021 / Published online: 12 February 2021

(c) The Author(s) 2021

\begin{abstract}
Constructions of dams influence river courses by cutting off sediment delivery and altering flow regime. We conducted flume experiments to study how sediment starvation, flow deficit and occurrence of series of floods with sediment load influence the evolution of channel planform. Results indicated that reduced flow caused a transition from a braided to incised single-thread planform with remains of inactive channels. The planform resembled rivers suffering from flow reduction caused by dams and constructions of irrigation canals (e.g., Central Platte River, USA). Simulation of series of floods with no sediment delivery caused the formation of an anabranching planform with incised main channel, alluvial islands, and side channels active at high flows. This evolution corresponds to river courses altered by sediment starvation and series of floods (e.g., the lower Drava River, Hungary). Floods with delivery of fines created a single-thread, incised channel with terraces along banks. Such channels are formed by rivers closed by dams, and compensating sediment deficit by sediment load from tributaries and/or floodplains (e.g., the Green River, USA). The flume tests demonstrated how flow and sediment deficit influence river channels and that the potential for restoration strongly depends on possibilities for the activation of sediment supply. However, restoration of pre-dam conditions is often impossible owing to other hydro technical works and land use changes. The highest restoration potential refers to the rivers compensating sediment delivery blocked by dams with tributary and floodplain resources.
\end{abstract}

Keywords River planform · Human impact on fluvial systems $\cdot$ Dam construction · Flume experiments

\section{Introduction}

What is the reason for the great diversity of river channel patterns? What are the factors that influence river channel evolution? These questions have troubled fluvial geomorphologists and river engineers for a long time, hence a large number of research studies have been devoted to this topic. Many river courses are subjected to changes in the flow magnitude, and sediment transport. These changes may be the natural features of a hydrological regime, and can

Kinga Kiss

kissk@gamma.ttk.pte.hu

1 Adam Mickiewicz University, Faculty of Geographic and Geologic Sciences, ul. B. Krygowskiego 10, 61-680 Poznań, Poland

2 University of Pécs, Faculty of Sciences, Institute of Geography and Earth Sciences, Ifjúság Útja 6, Pécs 7624, Hungary be characterized by cyclic (seasonal) character. However, in many cases such changes are caused by anthropogenic actions such as dam closure, sand mining and constructions of drainage or irrigation canals (e.g., Surian 1999; Rinaldi 2003; Horn et al. 2012; David et al. 2016; Słowik et al. 2018). Global damming of rivers resulted in changes that have no reference in the evolution of rivers in the past. Most frequent changes caused by dam closure are the reduction of flow magnitude and peak discharges, elimination of upstream sediment delivery, and bed incision (Williams and Wolman 1984; Grant et al. 2003; Pets and Gurnell 2005). These changes affect the life of communities dependent of river resources such as seasonal flooding (Nguyen et al. 2016; Latrubesse et al. 2017, 2020) and the presence of fish habitat (e.g., Pasha et al. 2015). Further dam constructions will seriously affect the life of people in developing countries (Cutler et al. 2020). Sediment starvation caused by dam closure exerted an impact on sedimentation in coasts 
and deltas (Syvitski and Kettner 2011; Kondolf et al. 2014; Nguyen et al. 2016).

Rivers were subjected to various the human-induced changes prior to dams constructions. For instance, the incision of the lower Drava River (Hungary) was started by channel straightening in the eighteenth century. This process was enhanced by dams constructions since 1958 . The effect was the exposure of channel bars, which, in turn, caused vegetation encroachment, stabilization of bars and formation of alluvial islands (Kiss and Balogh 2015; Słowik et al. 2018). Rivers may react in a variety of ways to dam closure. For instance, sediment starvation caused by dam construction may be compensated by delivery from tributaries and/ or valley floor and slopes [e.g., Dean and Schmidt 2013, Rio Grande (USA); Grams and Schmidt 2002 and 2005, the Green River (USA)].

Three methods are used commonly for the determination of the factors that influence river planforms evolution: (i) field surveys, (ii) numeric modelling, and (iii) laboratory experiments. Each of the methods has its own limitations and advantages. Field research allows for the collection of huge amount of data; however, the collected information may often be the record of the joint influence of a number of both natural and human-induced factors. Flume experiments are burdened by scaling issues (cf. Kleinhans et al. 2014). Certain parameters like grain size of the modeling media, cannot be scaled down. This shortcoming, however, can be partially overcome and compensated with higher slopes to increase the mobility of coarser sediment (Peakall et al. 1996; Kleinhans 2010).

Numerical modelling can be fully controlled. This limits the reality of obtained results, although, with increasing computational capacity, numerical simulations are becoming more and more useful for modelling the behavior of complex systems of river channels in large spatial and temporal scales (e.g., Nicolas et al. 2013; Schuurman and Kleinhans 2015; Yang et al. 2017; Weisscher et al. 2019).

Flume experiments are useful tools to test the influence of erosion and deposition processes on river behavior despite elimination of other factors occurring in real rivers. Laboratory tests have been applied to model channel evolution since the late 1800s. The largest flume ever built has been the downscaled replica of the Mississippi River, constructed in 1944 to support flood control planning and procedures along the river (Foster 1971). Leopold and Wolman (1957) applied a constant discharge and sediment feed to simulate the evolution of a braided stream. Struiksma et al. (1985) used curved flumes, characterized by various sinuosity and radii of curvature, to study changes in morphodynamics of bedforms and flow structure in meandering channels. Schumm and Khan (1971) analyzed the effect of slope on river pattern, then later (1972) the combined effect of slope and sediment load. They found that there is a close relationship between slope and sediment load concentration. With low slope, river channels remain straight. With increasing slope and sediment load, the planform is transformed from straight to sinuous, and then to a braided pattern. Schumm and Khan (1972) also found that channel patterns do not change progressively but quickly when reaching a critical erosional and/or depositional thresholds. They also discovered that the presence of silts in sediments added to a river bed contributes to the formation of meanders. Hundey and Ahmore (2009) used constant flow, sediment feed and slope to determine relations between channel width and the formation of confluences, bifurcations and channel bars in braided rivers. Van Dijk et al. $(2012,2013)$ transversely moved the inlet point and added fines (silt-sized silica flour) to the flume to simulate conditions necessary for the formation of meanders and cutoffs. Their flume tests allowed for determining the influence of upstream flow perturbations and delivery of fines on the formation of an actively migrating meandering planform. They demonstrated that vegetation is not an essential factor on the formation of meandering rivers. Métivier et al. (2016) found that river channels widen due to increased sediment transport. When the channel reaches a given threshold width it is transformed into an unstable braided river.

Recent studies used close range photogrammetry for the monitoring of morphological changes during flume experiments, including the simulation of forming floodplain sedimentary architecture (van de Lageweg et al. 2013, 2016). Generation of 3D models at specified time intervals was found to be an efficient way measuring the topographic changes of channels and bedforms in flumes (Leduc et al. 2019). Norizan et al. (2016) analyzed the effect of alternating flooding and non-flooding events on channel evolution, employing close range photogrammetry for recording changes during flume experiments.

The main goal of our study was to determine the influence of sediment starvation, flow deficit and occurrence of series of floods on the evolution of channel planform. Our study is based on flume tests that allowed for a simulation of effects of alternating flows and channel incision on channel planform evolution. The research tasks included: (i) to track the evolution of river planform in various flow and sediment delivery conditions, and (ii) compare the results of the flume experiments with the evolution of real river courses. Previous research based on flume tests aimed, e.g., to simulate the influence of vegetation on bank stabilization and formation of a meandering planform (Tal and Paola 2007; Braudrick et al. 2009), and the influence of flow variability and presence of fines on the prevention of erosion and bank stabilization (Métivier et al. 2016), and formation of meandering rivers and cutoffs (e.g., Schumm and Khan 1972; van Dijk et al. 2012, 2013; Li et al. 2019). In our flume tests, we decreased the magnitude of discharge (test 1), simulated flood events by temporal increase of the flow (test 2), and 
floods accompanied by additional sediment load (test 3 ) to track processes taking place in rivers affected by such events.

\section{Research methods-setup of flume experiments}

The flume tests were carried out using the PTETHYS (Project for Tectonical and Hydrological Simulations) flume at the University of Pécs (Fig. 1). The flume can be adjusted and tilted both around its longitudinal $\left(7.5^{\circ}\right)$ and transversal axes (up to $10^{\circ}$ ) and has adjustable push-blades both vertically and horizontally. Six sections can be moved vertically and it has 4 push-blades which allows lateral deformation. These adjustments enables the execution of various experiments including tectonic and morphological processes. These motions are controlled by computer-governed electro-engines. Thus water and sediment could leave the flume only through a sink in its downstream part (Pirkhoffer et al. 2014).

The experimental area is $4.2 \times 2.5 \mathrm{~m}$, which can hold up to $2500 \mathrm{~kg}$ of sediment. For modeling purposes a $1 \mathrm{~m}$ wide section of the entire flume was used where the bottom was made of plexiglass and for the lateral constrains of the flow wooden boards were used (see Fig. 1). The bottom of the flume was also secured using plexiglass to prevent the infiltration. Discharge was measured and regulated by a flow meter.

Three experiments, simulating downstream hydrological impacts of dam operations, and sediment delivery scenarios, were conducted. All the experiments were started with a straight channel $(3 \mathrm{~cm}$ deep and $5 \mathrm{~cm}$ wide). The material used in these experiments is color-coded; the colors of grains indicate grain size. Coarse grains are grey ground basalt $(1.0 \mathrm{~mm})$ and black andesite $(0.8 \mathrm{~mm})$. The $0.6 \mathrm{~mm}$ diameter grains are of red marble and the $0.2 \mathrm{~mm}$ diameter are of beige limestone. Particle-size distribution of the experimental material is shown in Table 1 . When scaling down the material placed in a flume to the volume of the flow used in experiments, sediment mobility may be low or below the threshold of motion (cf. Kleinhans et al. 2014). Therefore, we used in our flume tests relatively high slopes (from $1^{\circ}$ to $5^{\circ}$ ) compared to these occurring in real rivers. This allowed for the activation of sediment transport in our flume tests, and resulting changes in the channel morphodynamics and planform.

During the flume tests, pictures of planform changes were taken every $60 \mathrm{~s}$ using 8 Canon EOS 1100D (4 Samyang

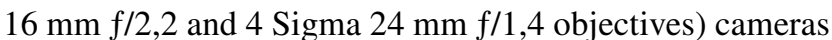
installed on a system of cantilevers above the experimental area. They are connected to a computer with USB ports, so images are taken with each camera concurrently. Pictures are overlapping by $80 \%$, allowing the calculation of
3D models of the planform. Ten markers (ground control points) were used as reference in the experimental area and their coordinates were measured by a Sokkia total station in a local coordinate system. This way the resulting 3D models are in the same coordinate system and distances can be determined. For image processing Agisoft Metashape 1.5.3 was used, which is used for the calculation of orthophotos and digital elevation models using the synchronous images. Digital elevation models were processed in ArcMap 10.6.2. Based on the obtained models, cross-sections illustrating channel planform changes in selected stages of the flume tests were obtained.

All the flume tests started with a straight channel, and a certain time was needed for the channel to evolve to a state with active morphodynamics, in conditions of decreasing discharge or sediment deficit. Therefore, the detailed analysis of the channel planform changes refers to part of the conducted experiments; changes of the planform in flume test 1 were shown between 30 and 70 min. since the activation of the straight channel. Periods between 45 and $68 \mathrm{~min}$ of the experiments were analyzed for flume tests 2 and 3 (Fig. 2), to compare the morphodynamics in conditions of subsequent floods, and floods with additional flow and sediment delivery volume.

\section{Test 1-simulation of decreased discharge on planform evolution}

The experiment was conducted as follows (Fig. 2a):

- a $1.5 \mathrm{l} / \mathrm{min}$ discharge was set to flow through a straight channel (duration: $35 \mathrm{~min}$ ),

- the discharge was decreased to $1.0 \mathrm{l} / \mathrm{min}$ (duration: $20 \mathrm{~min}$ )

- the flow was decreased again to $0.5 \mathrm{l} / \mathrm{min}$ (duration $20 \mathrm{~min})$.

During the test the slope of the flume was constant $\left(3^{\circ}\right)$.

\section{Test 2-simulation of influence of subsequent floods and increased slope on planform evolution}

The experiment was carried out in the following way (Fig. 2b):

- the slope was successively increased from $1^{\circ}$ to $5^{\circ}$ in $0.5^{\circ}$ intervals. Each of the intervals lasted $10 \mathrm{~min}$.

- during each of the intervals the flow was changed as follows: $2.5 \mathrm{l} / \mathrm{min}$-duration $1 \mathrm{~min}, 1.5 \mathrm{l} / \mathrm{min}$ - duration $4 \mathrm{~min}, 2.5 \mathrm{l} / \mathrm{min}$-duration $1 \mathrm{~min}, 1.5 \mathrm{l} / \mathrm{min}$-duration $4 \mathrm{~min}$ (Fig. 2b). The aim was to simulate sequences of floods occurring in the Drava valley after 1989 when 

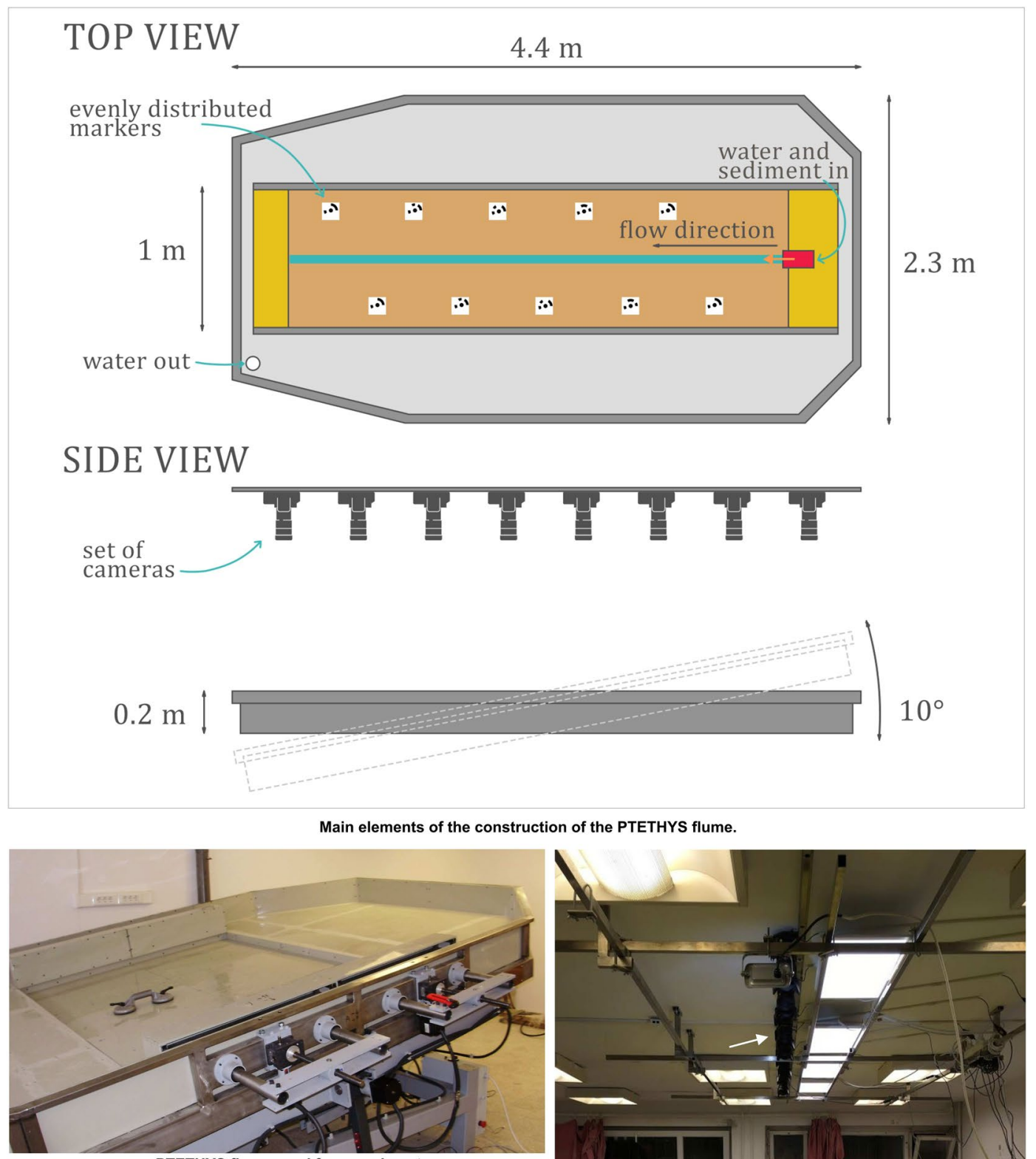

PTETHYS flume used for experiments

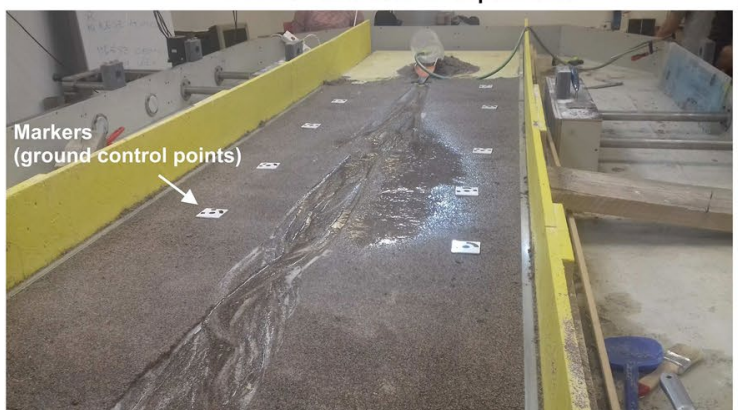

The flume filled with sand material during one of tests. White plates in lateral parts of "floodplain" are markers necessary to inegrate photos from cameras into one image.

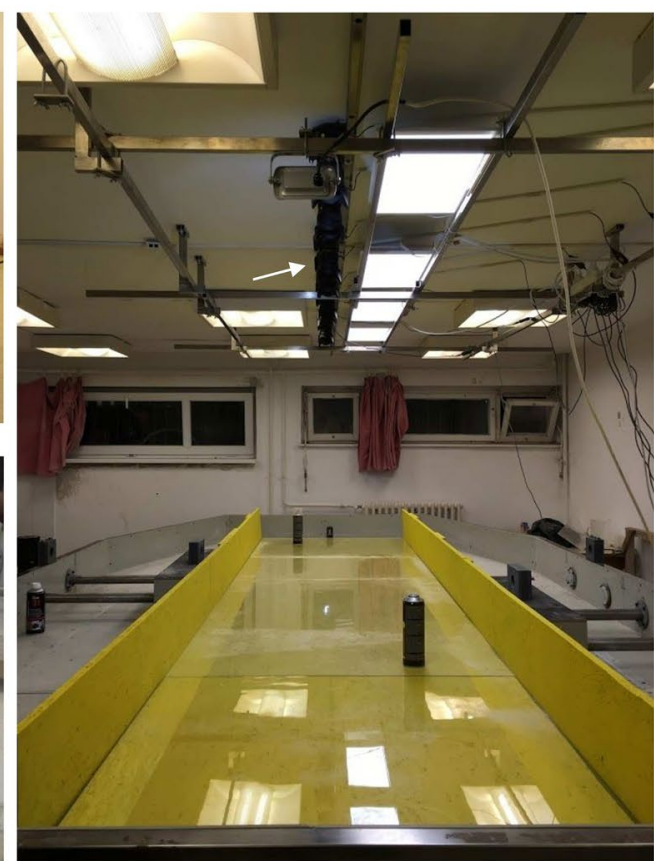

Set of cameras (marked by white arrow) to image particular stages of the flume tests

Fig. 1 Images illustrating the construction of the PTETHYS flume 
Table 1 Grain-size properties of sediments used in the flume tests

\begin{tabular}{lc}
\hline Fraction & Percentage \\
\hline $1-2 \mathrm{~mm}$ & 0.34615 \\
$500-1 \mathrm{~mm}$ & 66.57948 \\
$355-500 \mu \mathrm{m}$ & 18.21738 \\
$250-355 \mu \mathrm{m}$ & 7.20981 \\
$100-250 \mu \mathrm{m}$ & 4.56918 \\
$<100 \mu \mathrm{m}$ & 0.8901 \\
\hline
\end{tabular}

the construction of the lowermost dam near Botovo was completed.

\section{Test 3-simulation influence of floods with sediment load and increased slope on planform evolution}

In the third of the experiments, the slope was increased as in test 2 . However, the 1 min intervals of increased flows were enhanced by adding 11 of water with $20 \mathrm{~g}$ of sediments of diameter $<250 \mu \mathrm{m}$ (Fig. 2c) during each of the floods. The additional volume of water (1 l) was selected as higher volumes would cause too intensive eroding of the sediments placed in the flume, and lower volumes would not exert a visible influence on the evolution of simulated channel planforms.

As we treated sediments placed in the flume by the volume of water with no sediment load (tests 1 and 2) or such load was added only during simulated flood events, the simulated channel planforms were eroded by downstream propagating erosion. The erosion formed a straight channel cutting along fluvial forms shaped in the flume. These changes appeared after $70 \mathrm{~min}$. of each of the tests (Fig. 2). We could not extrapolate the pace of the downstream erosion observed in the flume to the propagation of river bed incision occurring in real rivers downstream of dams.
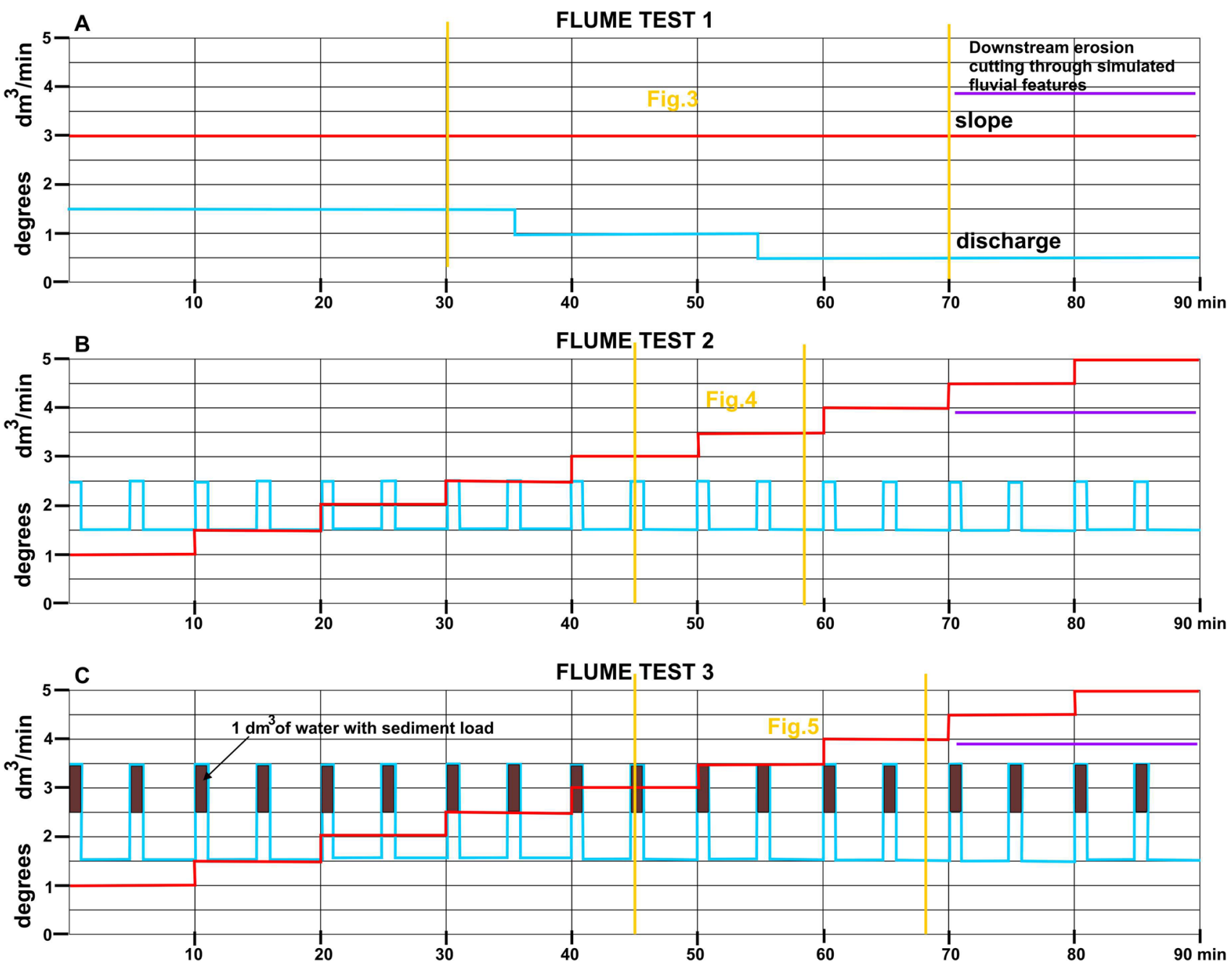

Fig. 2 Setup of the flume experiments 


\section{Results}

\section{Evolution of channel planform in flume test 1}

The first of the experiments was conducted at a constant slope $\left(3^{\circ}\right)$. The discharge at the start of the flume test measured $1.5 \mathrm{l} / \mathrm{s}$ (Fig. 3). In such conditions the river bed evolved from a straight channel, through the formation of a sequence of alternate bars, to a sequence of side bars. The largest of them has been preserved in the upstream part of the flume (Fig. 3a-d). Moreover, a bifurcation was formed on the left side of the floodplain. The bifurcation conveyed part of the flow through two channels. After $30 \mathrm{~min}$ of the experiment the channel planform was braided with three mid-channel bars, two side bars "attached" to the banks, and the bifurcation consisting of two channels (Fig. 3a; Table 2).

After decreasing the flow to $1.0 \mathrm{l} / \mathrm{s}$, the bifurcation became temporarily inactive (Fig. $3 b$ ). 5 min after the decrease of the flow ( $40 \mathrm{~min}$ of the test) the flow was conveyed by a single channel characterized by a sequence of alternating side bars (Fig. 3b). At 50 min. of the test, the flow was directed to one of the channels forming the bifurcation (Fig. 3c1). The flow was conveyed by this channel to the floodplain. This was caused by in-channel deposition, resulting in the formation of a channel bar that blocking the main channel (Fig. 3c1). This is illustrated by a shallow cross-section of the main channel (see line I in Fig. 3). However, this was a short-duration event. At $55 \mathrm{~min}$. of the test, the flow in the main channel was reactivated (Fig. 3c2). The overbank flow was discontinued but the floodplain remained saturated; water was stagnating on its surface downstream of the bifurcation (Fig. 3c2).

After further decrease of the flow to $0.5 \mathrm{l} / \mathrm{s}$, the flow was conveyed through the main channel. The incision of the main channel propagated downstream (Fig. 3d). This is also illustrated by cross-sections of the main channels in lines I and III (see cross-sections in Fig. 3). Channel incision also commenced in the downstream part of the flume. In this way the side bars situated at both sides of the main channel were positioned at a higher level in relation to the incised main channel, and became inactive (Fig. 3d; Table 2). At the same time, bifurcation also became inactive. This is marked by a deposition in one of the bifurcating channels after 55 and 70 min of the test (see cross-section II; Fig. 3). However, the line illustrating the channel bottom after $70 \mathrm{~min}$. is probably elevated, possibly owing to reflections from surface water.

\section{Evolution of channel planform in flume test 2}

During the first 45 min of the test the planform evolved from a straight to braided planform with downstream migrating mid-channel bars. The barforms were inundated during a flood event simulated in $45 \mathrm{~min}$ of the test at a slope of $3^{\circ}$. The flow commenced over the entire width of the channel, and the channel was widened (Fig. 4a). In the following period of a low flow, four channel bars were exposed (Fig. 4b).

After increasing the slope to $3.5^{\circ}$, the channel bars were eroded during a flood at $50 \mathrm{~min}$. of the flume test (Fig. 4c). The first flood at a slope of $3.5^{\circ}$ caused the formation of scour channels in the channel bar in the middle part of the flume (Fig. 4d). In periods of low flows, the side channels became inactive, and the channel bars were exposed. This is expressed by an increase in the surfaces of channel bars in this period (see diagram in Fig. 4). The channel bar exhibited a characteristic undulating surface with inactive scour channels (Fig. 4d). Moreover, three channel bars with adjacent side channels were formed in its downstream part. The channel was successively widened.

During the second flood at a slope of $3.5^{\circ}$ (55 $\mathrm{min}$ of the test; Fig. 4e) a set of scour channels was formed by the overbank flow that inundated the floodplain along the right bank. The scour channels were reactivated and the bar in the middle part of the flume was divided into three smaller barforms (Fig. 4e). This is also illustrated by cross-sections II and III (Fig. 4h). All the barforms were inundated during the flood and the channel width increased. This is also indicated by a decrease in the number of barforms (see Fig. 4g).

The flood simulated at $55 \mathrm{~min}$. of the experiment caused the incision of the main channel (see cross-section I; Fig. 4h). In the following period of low flows (58 min. of the test; Fig. 4f), side channels located between channel bars and bank were inactive as they were situated at a higher level than the main channel (see cross-sections II and III in Fig. 4h). The second of the floods left a number of channel bars separated from the floodplain by side channels, also in the downstream part of the flume (cross-sections IV and V; Fig. 4h). Their total surface increased by close to $100 \%$ (from 0.08 to $0.148 \mathrm{~m}^{2}$ ) compared to the previous period of low flows (Fig. 4g). In the upstream part of the flume, three bar cut by scour channels merged into one; the traces of the scour channels have been preserved in the "alluvial island" surface (see Fig. 4f and cross section II and III). Since the island existed until the bankfull stage was exceeded, the channel planform may be defined as anabranching (cf, Nanson and Knighton 1996). Nanson and Knighton (1996) define the anabranching planform as "a system of multiple channels characterized by vegetated or otherwise stable alluvial islands that divide flows at discharges up to nearly bankfull". This meets the conditions obtained in the laboratory tests except for vegetation impact. This means that this type of channel planform can also be formed without the presence of vegetation. 

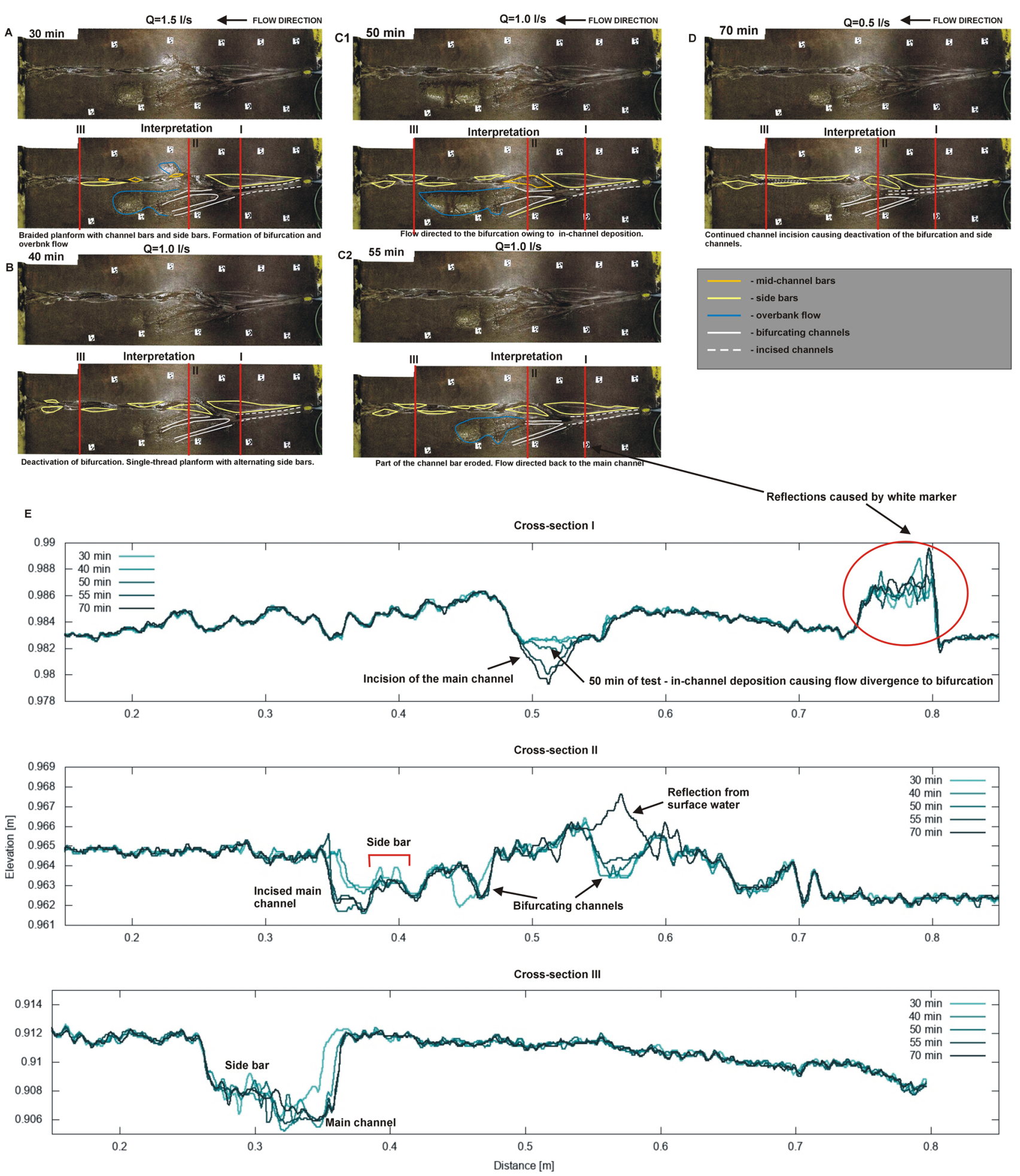

Fig. 3 The evolution of channel planform at decreasing discharge (flume test 1). a A braided planform after $30 \mathrm{~min}$ of the experiment, with a bifurcation conveying part of the flow by two channels, $\mathbf{b}$ after the flow decrease the flow commences through a single channel, c1 reactivation of the bifurcation due to in-channel deposition, $\mathbf{c} 2$ return of the flow path to the main channel, $\mathbf{d}$ the planform become morphologically inactive; the flow is too weak to transport sediments and make any changes in the planform. e cross-sections illustrating evolution of channel planform during the experiment 


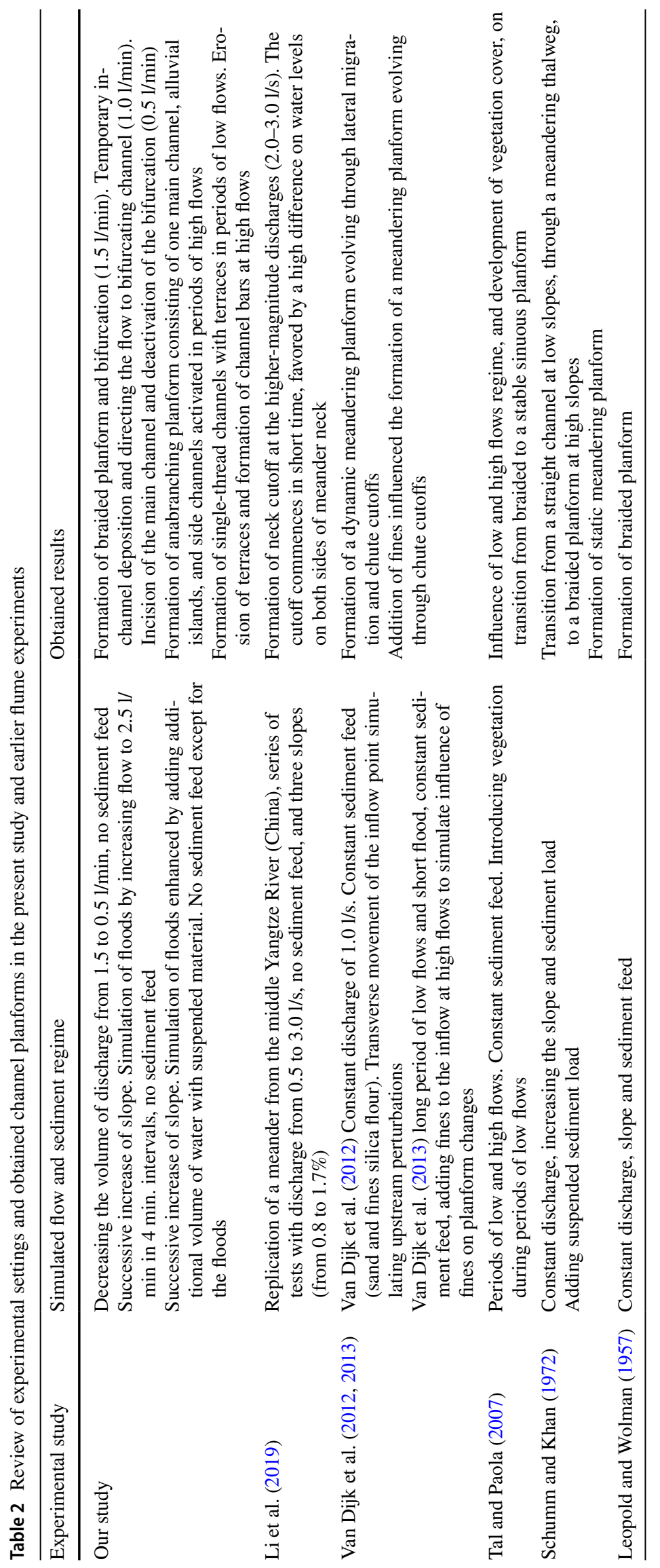



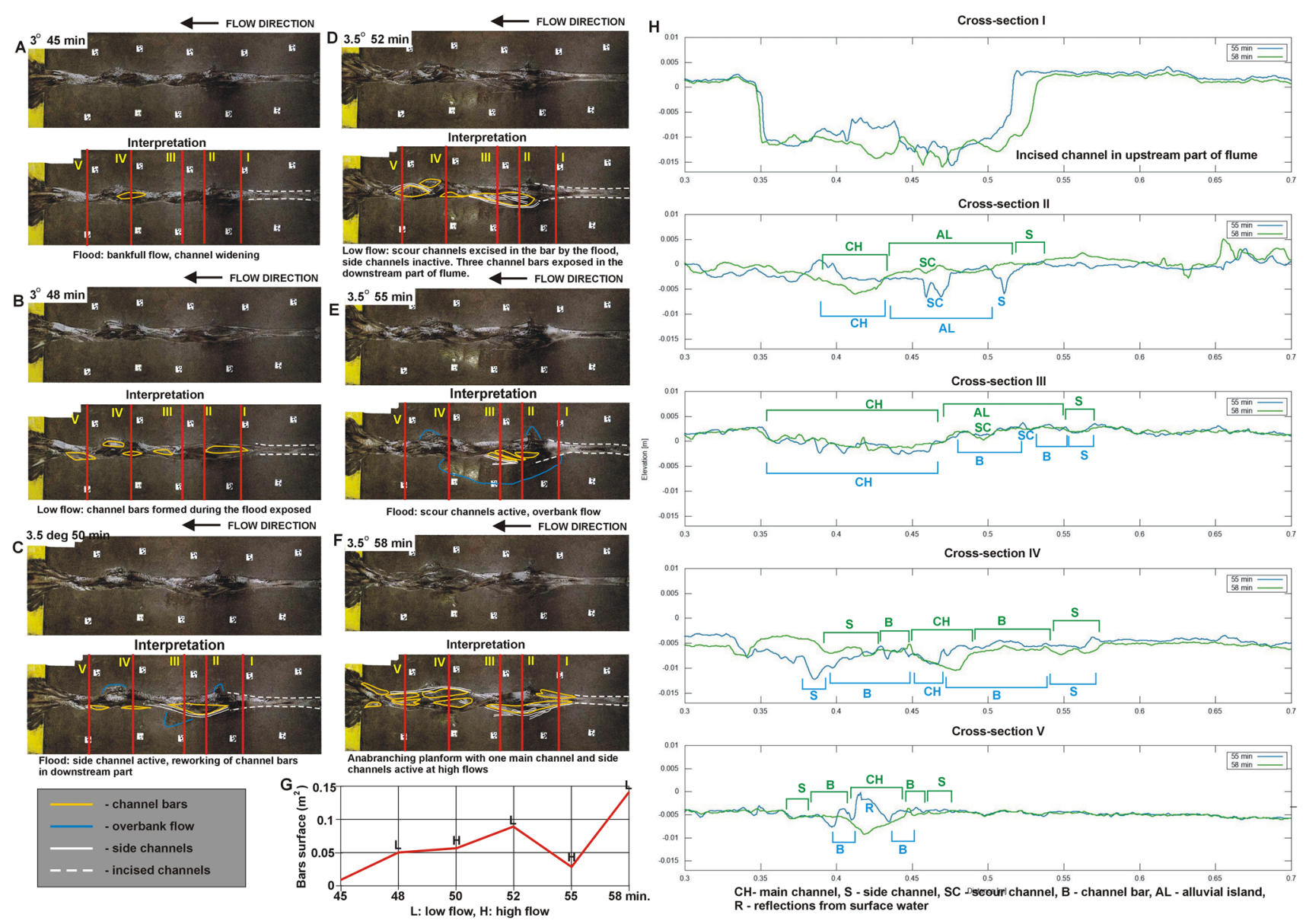

Fig. 4 Channel planform changes during a sequence of floods and increasing slope (flume test 2). The diagram in Fig. $5 \mathrm{~g}$ shows changes in the surface of bars during particular stages of the experiment

The final products of the flood were exposed in a period of low flows (Fig. 4f; Table 2):

- channel bars with traces of scour channels in the middle and downstream part of the flume. They are also illustrated by cross-section II (line II; Fig. 4h).

- all the channel bars separated from the banks by side channels

- the sequence of floods simulated in the experiment caused a successive increase of bar surfaces (see a diagram in Fig. 4); during floods the bars were reworked or inundated whereas in periods of low flows the amount of bars increased owing to conveying the flow by incised main channel.

- the test at 3.5 and 4.0 degrees also shows that together with the repeated sequence of high flows and river bed incision the process of bar merging, the formation of alluvial islands and repeated activation/deactivation of side channels propagated downstream.

- owing to the successively increased surface of channel bars, the hierarchy of channels (one main channel and a number of side channels active at high flows), and their persistence until the overbank flow occurred, the obtained channel planform can be defined as anabranching.

\section{Evolution of channel planform in flume test 3}

As in the previous tests, the evolution of the planform started with a straight channel, and downstream migration of alternate bars. When the slope was increased to $3.0^{\circ}$, channel bars were formed during a flood at $45 \mathrm{~min}$. of the experiment in the middle part of the flume (see Fig. 5a, b, and cross sections III and IV; Fig. 5h). Terrace levels were present in the upstream and downstream part of the flume (cross-sections I and VI; Fig. 5h). In period of low flows that followed the flood (48 min. of the test, Fig. 5b), the surface of terrace levels increased (see Fig. 5h and cross-sections - Fig. 4h). The terraces were situated at a higher level due to channel incision.

At a slope of $3.5^{\circ}$, channel bars were formed again during the first of the simulated floods (Fig. 5c). In the following 

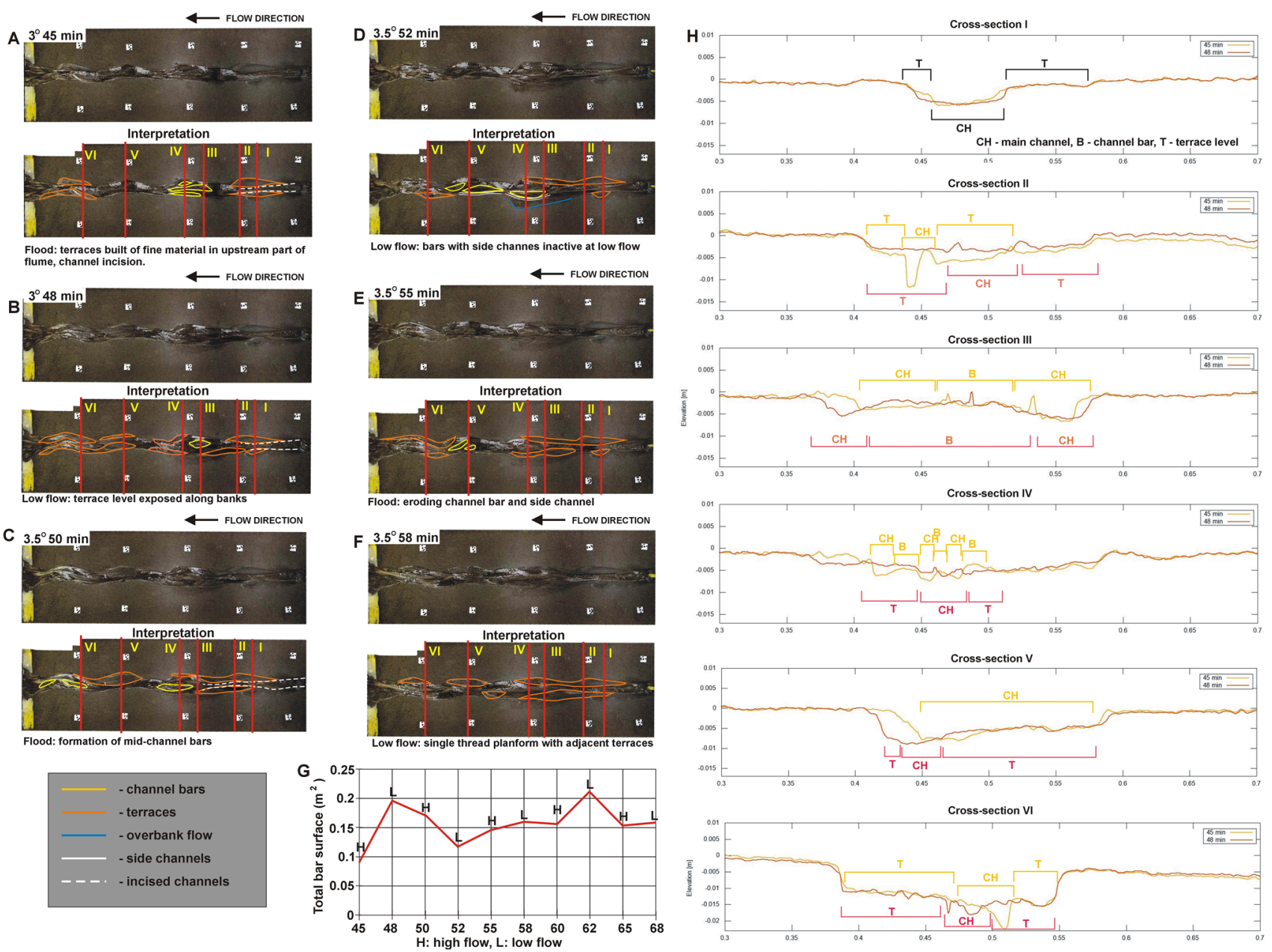

Fig. 5 Channel planform changes during a sequence of floods with delivery of fines, and increasing slope (flume test 3 ). The planform evolved through channel incision, and formation of terraces along

period of low flows they were separated from banks by side channels (Fig. 5d). The side channels were inactive at low flows. However, the channel bars and the side channels were eroded by the second flood at $55 \mathrm{~min}$ of the test (Fig. 4e). In the following periods of low flows the flow commenced through a single channel with adjacent terraces and a single channel bar (Fig. 5f).

When the slope was increased to $4^{\circ}$, the terraces were eroded, and two channel bars appeared during the first flood in the $60 \mathrm{~min}$ of the test (Fig. 5i). In period of low flows (62 min of the test; Fig. 5j; Table 2) the planform returned to the incised single-thread channel near-continuous terraces. The process of eroding of the terraces and formation of bars during floods, and deposition along banks and formation of terrace levels at low flows, is illustrated by cross-sections I-VIII (Fig. 5m). The erosion of the terraces was repeated by the second flood at this slope (Fig. 5k). This flood event also caused the formation of an alluvial island characterized banks. The terraces were eroded by subsequent floods, during which channel bars were formed

by undulating surfaces owing to the formation of scour channels. The island is well seen during the periods of low flows (Fig. 51), when the scour channels were inactive. In these periods, the main channel returned to the incised, sinuous planform.

Compared to test 2, the delivery of fines during each of the floods influenced a deposition along the channel banks resulting in the formation of the terrace levels. This is confirmed by relatively small changes in the total surface of bars during test 3 in relation to experiment 2 (see diagram in Fig. $5 \mathrm{~g}$ ).

\section{Discussion}

Our experiments allowed for the simulation of processes taking place in rivers affected by flow reduction (Fig. 3), sediment-starved regimes (Fig. 4), and rivers where sediment 


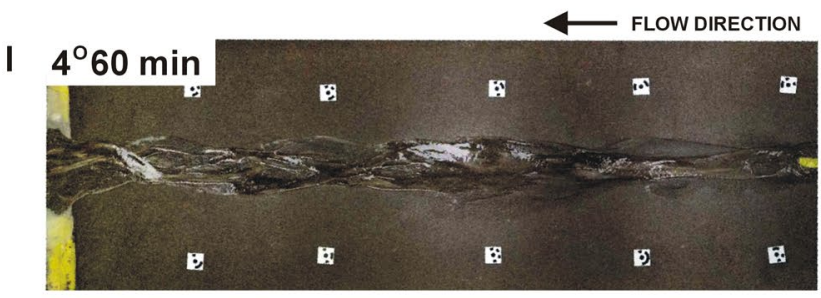

Interpretation

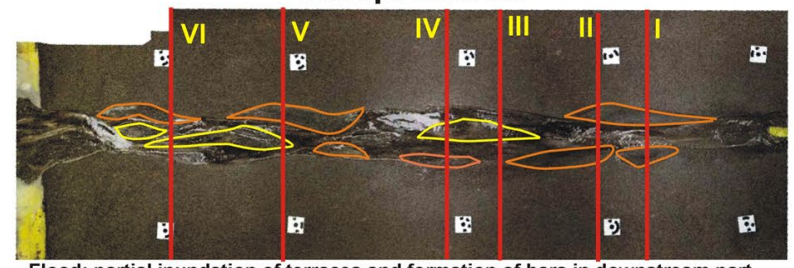

Flood: partial inundation of terraces and formation of bars in downstream part of flume
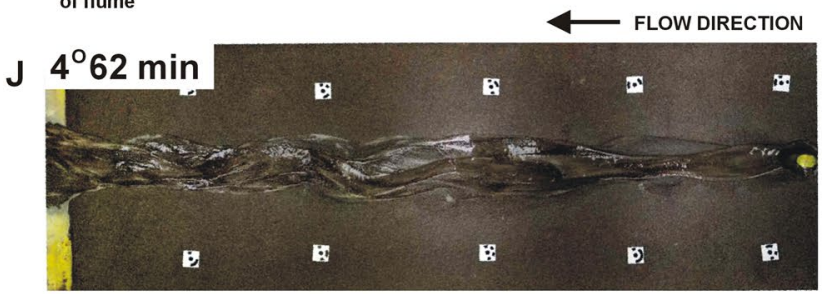

Interpretation

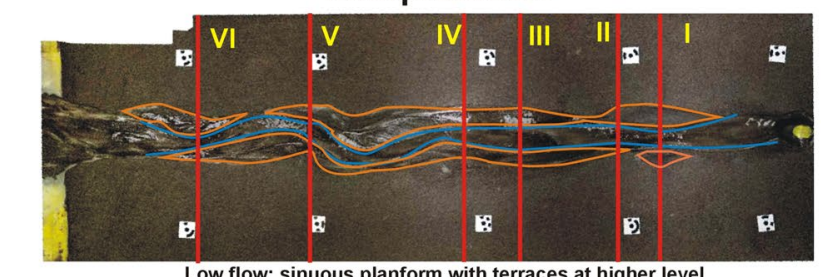

Low flow: sinuous planform with terraces at higher level 4 FLOW DIRECTION

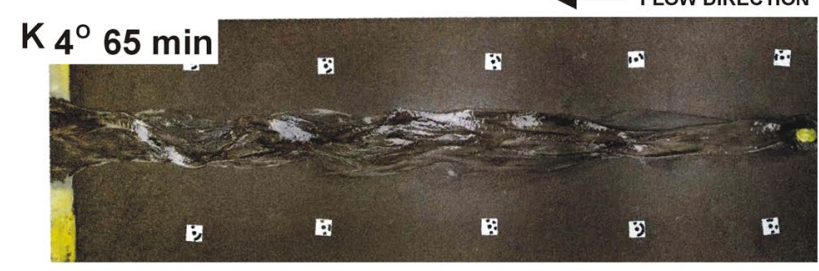

Interpretation

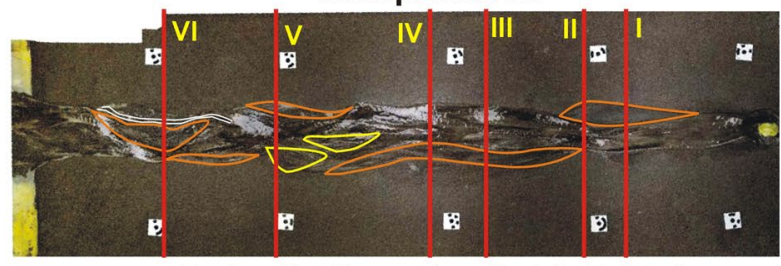

Flood: eroding of terraces, tramsition to braided planform

Fig. 5 (continued)

load is delivered during floods (Fig. 5). Previous flume studies demonstrated the influence of vegetation cover (Tal and Paola 2007; Braudrick et al. 2009), upstream perturbation (van Dijk et al. 2012), and presence of fines (Schumm and Khan 1972; van Dijk et al. 2013) on the formation of meanders (see Table 2). We have proved in laboratory test 2 that
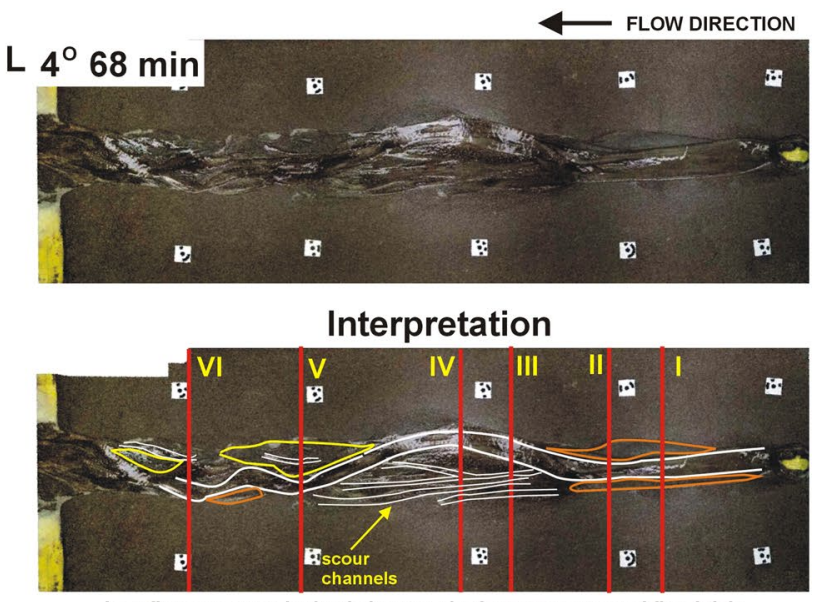

Low flow: return to incised sinuous planform, terraces and floodplain reworked by scour channels inactive at low flow.
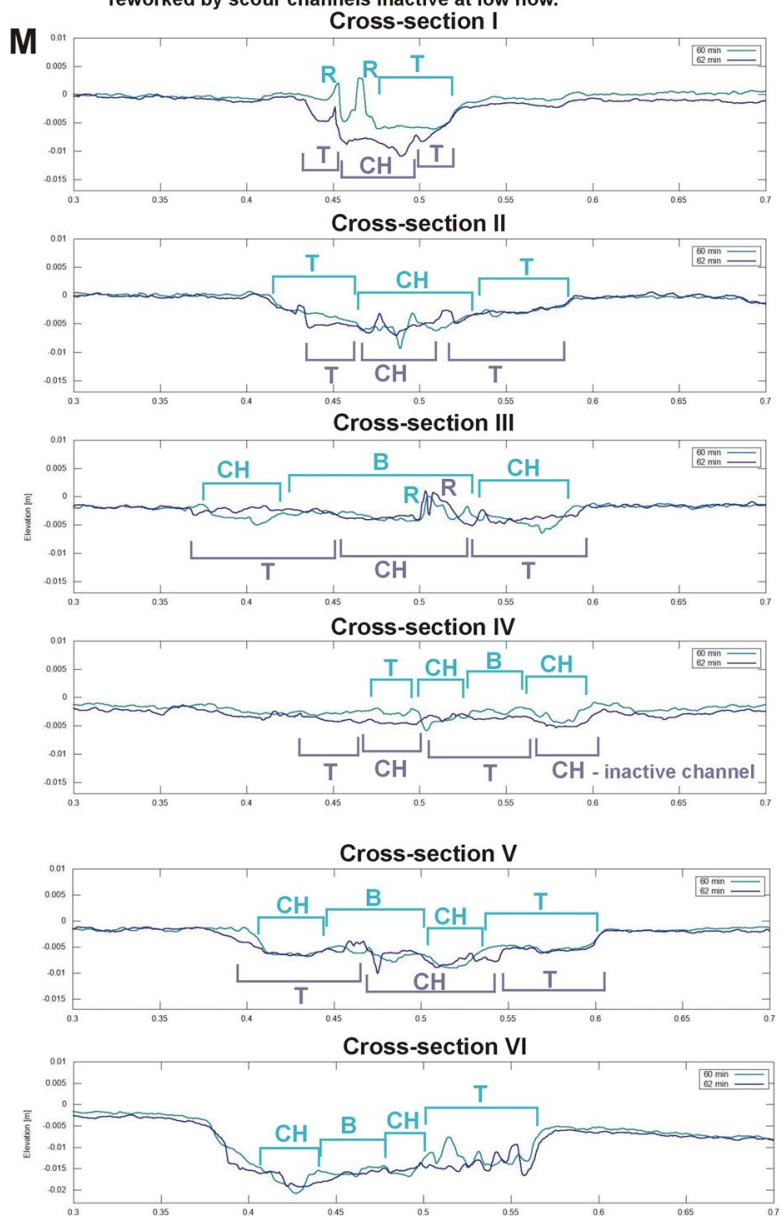

$\mathrm{CH}$ - main channel, B - channel bar, T - terrace level

series of floods can lead to the formation of an anabranching planform, and this can happen without the presence of vegetation and input of fines. Series of floods alternating with periods of low flows trigger the formation and coalescence of channel bars, formation of side channels and scour channels within the alluvial islands are sufficient for 
the formation of anabranching planforms. This is confirmed by examples of real dryland river courses evolving without vegetation (e.g., Li et al. 2015). In the case of Rio Capilla the discharge regime was characterized by seasonal occurrence of floods the result of natural hydrological regime, not dam closure. The influence of series of floods on the development of anabranching planform with meandering anabranches was also demonstrated in the study of Słowik (2018) in the middle Obra River valley (Poland).

Similar to flume tests conducted by Leopold and Wolman (1957), and Schumm and Khan (1972), we observed the formation of alternate bars, that later merged into larger bedforms. Schumm and Khan (1972) observed merging of channel bars and formation of alluvial islands, however, without the main incised channel. This is because they used a constant discharge and sediment feed that caused the widening of the channels near the alluvial islands (Schumm and Khan 1972). We applied variable flows, successive increase of the slope and no sediment feed in test 2 and this resulted in the formation of an anabranching planform characterized by the main incised channel and side channel active at high flows (Fig. 4f; Table 2).

The addition of fines during floods simulated in test 3 caused the formation of terrace levels along a single-thread channel in periods of low flows (Fig. 5j). This is not in agreement with the results shown by Schumm and Khan (1972), and van Dijk et al. (2012), possibly owing to the fact that they applied a constant feed of fines. Van Dijk et al. (2012) applied delivery of fines along with transverse moving of the inflow point. These settings caused the formation of migrating meanders and chute cutoffs. In our test 3 , the inflow point was fixed in one place, and this resulted in the formation of a straight single-thread channel with terrace levels on its both sides (Fig. 5j). Similarly to laboratory tests performed by Li et al. (2019), our experiments exhibited increased eroding and reworking of channel banks when increasing the slope and discharge (tests 2 and 3; see, e.g., Figs. $4 \mathrm{c}$ and $5 \mathrm{i}$ ).

\section{Types of rivers simulated in flume experiments}

These experiments allowed for simulation of the evolution of the following types of rivers:

- rivers unable to rework and convey sediment sources available in floodplains. They evolve from wide channel belts comprising of a number of channels to a singlethread course with traces of inactive channels preserved in the floodplain. The main reason is a decrease in the flow magnitude caused by constructions of dams, systems of irrigation canals and use of water for municipal needs. The evolution of the channel pattern in flume test 1 is similar to changes in the course of the central Platte River
(USA) (Horn et al. 2012). Before dam construction, the river exhibited a high-energy braided planform evolving in a $1.3 \mathrm{~km}$ wide channel belt (see archival image from 1938 in Fig. 6). Dam closure, preceded by the construction of irrigation channels and diversion dams, caused a reduction of discharge, decrease of channel width from 25 to $50 \%$ and turned the channel into a single thread and anabranching planform, with a number of inactive channels (Horn et al. 2012) (see Fig. 6 for a comparison of the flume tests with changes of the real river course). Another example are rivers of northern Italy, affected by dam closure, sediment mining and channelization. These actions resulted in severe narrowing of active channels, producing inactive channels belts downstream of dams (cf, Surian and Rinaldi 2003; Surian et al. 2009). Possibilities of restoration in such cases are low in the above cases as dam constructions were accompanied or had been preceded by a number of other actions (mentioned above) that reduced water resources.

- rivers with a single incised channel, and alluvial islands and side channels situated at a higher level of the floodplain (Fig. 7). In such river courses, series of floods with limited or no sediment load cause bed incision, and formation of channel bars. The bars merge and, as the main channel continues to incise, are stabilized by vegetation and become alluvial islands. Side channels are activated by high flows or become part of the floodplain if the continued incision of the channel prevents this activation. Such an evolution describes rivers that were altered by dam constructions hence reducing bed load transport. This is the case, e.g., of the lower Drava River (Hungary) (Słowik et al. 2018), Rhone River (France) (Provansal et al. 2014), Garonne River (France) (David et al. 2016), Vistula River (Poland) (Gierszewski et al. 2015 and 2020) and the Arno River (Italy) (Rinaldi 2003). Some actions aiming to restore the activity of side channels and groundwater supply are undertaken in these river courses (e.g., the lower Drava River Lóczy et al. 2014). However, the success of these undertakings strongly depends on availability of sediment and water resources in river basins.

The second flume experiment allowed for simulation of such an evolution in conditions of frequent floods, and accompanying sediment starvation and bed incision. The obtained channel planform changes are similar to these observed in a real river course the lower course of the Drava River (Hungary) (cf, Słowik et al. 2018). The river was altered by dam construction and earlier humaninduced changes (channel straightening in the eighteenth and nineteenth century) (Słowik et al. 2018). The variability of water levels after closure of the lowermost dam in 


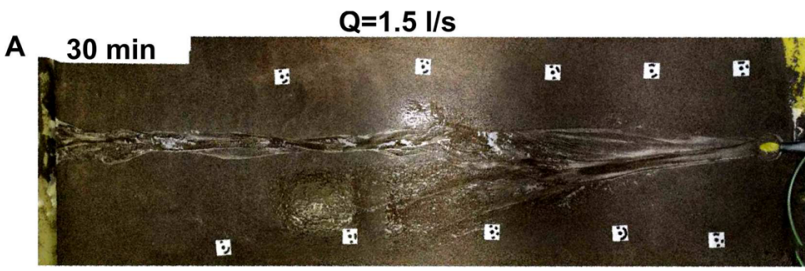

Interpretation

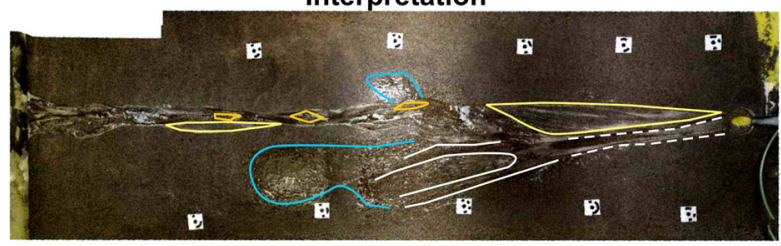

Braided planform with channel bars and side bars. Formation of bifurcation and overbank flow

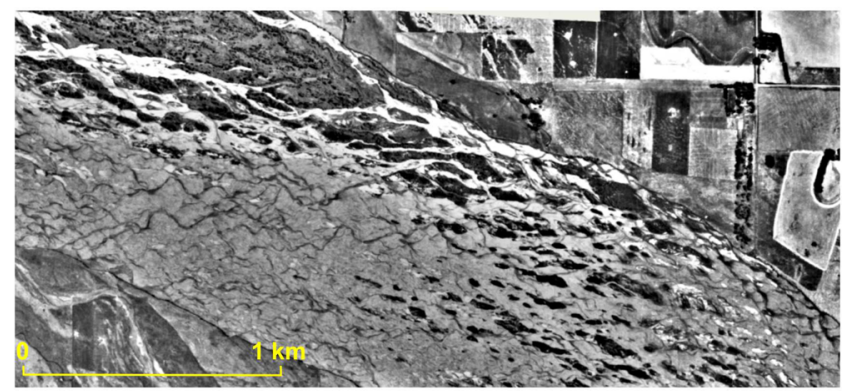

Central Platte before dam closure in 1938

Location: 7 km SE of Cozad (Nebraska, USA)

Source: arcgis webscene viewer

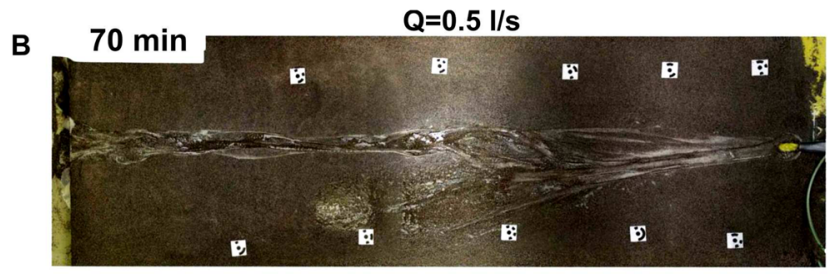

Interpretation

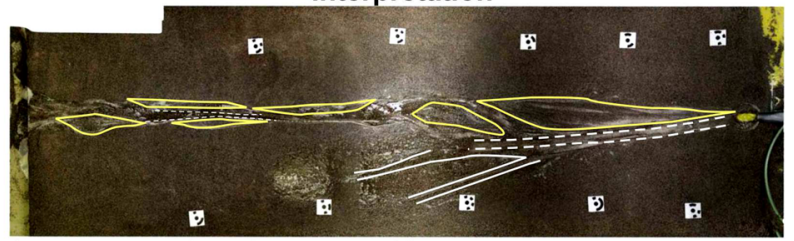

Single-thread planform after decrease of flow.

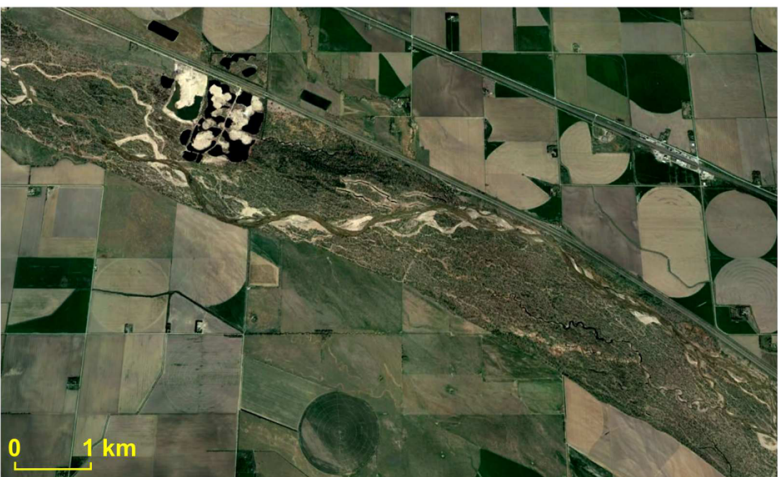

Single-thread planform of Central Platte River after dam closure (river section 7 km SE of Cozad, Nebraska, USA)

Source: Google Earth

Fig. 6 A comparison with channel planform obtained in flume test 1 with channel pattern changes of the central Platte River (USA)

1989 (Fig. 7a) was reflected in the experiment by series of high flows (Fig. 7b). These conditions resulted in the formation of channel bars and bed incision, which resembles similar processes after straightening of the Drava River bed in the eighteenth century (see Fig. 7c, d). Next, the planform evolved through continued incision of the main channels, formation of alluvial islands with scour channels formed by floods, and side channels active a high flows (Fig. 7e, f) similar to the lower Drava (cf, Słowik et al. 2018).

- rivers evolving through the formation of terrace levels and sediment benches causing channel narrowing (Fig. 8). In many cases the deposition is the effect of lowering the magnitude of flow and upstream sediment delivery owing to dam closure. The sediment deficit is compensated by sediment resources from tributaries and floodplain. If the flow volumes are smaller compared to these prior to dam closure, the channel narrows owing to the formation of the terraces and benches. In this group of rivers, restoration potential is the highest compared to rivers simulated by experiments 1 and 2 , as these courses have the highest ability to return to pre-dam conditions using their tributary and floodplain sediment resources.

Flume test 3 simulated a sequence of floods, enhanced by addition of surplus flow and the load of fines. The resulting formation and reworking of terrace material (part of which was built of fines), and channel bars in periods of floods, resemble to river valleys influenced by delivery of sediments from tributaries and/or floodplain. They may be also formed by controlled floods delivering sediment load in water courses altered by dam closure. The case of the Green River (USA) downstream of Three Gorges Dam (Fig. 8c) is the example of a real river course characterized by channel narrowing, and formation of elongate patches of floodplain along active channel by post-dam floods, and sediment delivery from floodplain, valley slopes and tributaries (cf, Grams and Schmidt 2002, 2005; Grams et al. 2019) (see also Fig. 8c). Peak flows were reduced from $500-600 \mathrm{~m}^{3} / \mathrm{s}$ in a pre-dam period to $200-300 \mathrm{~m}^{3} / \mathrm{s}$ after dam closure. Mean discharge decreased from 200-300 $\mathrm{m}^{3} / \mathrm{s}$ in a pre-dam period to $100-200 \mathrm{~m}^{3} / \mathrm{s}$ after dam construction (see Fig. 2 in Grams and Schmidt 2005). The 

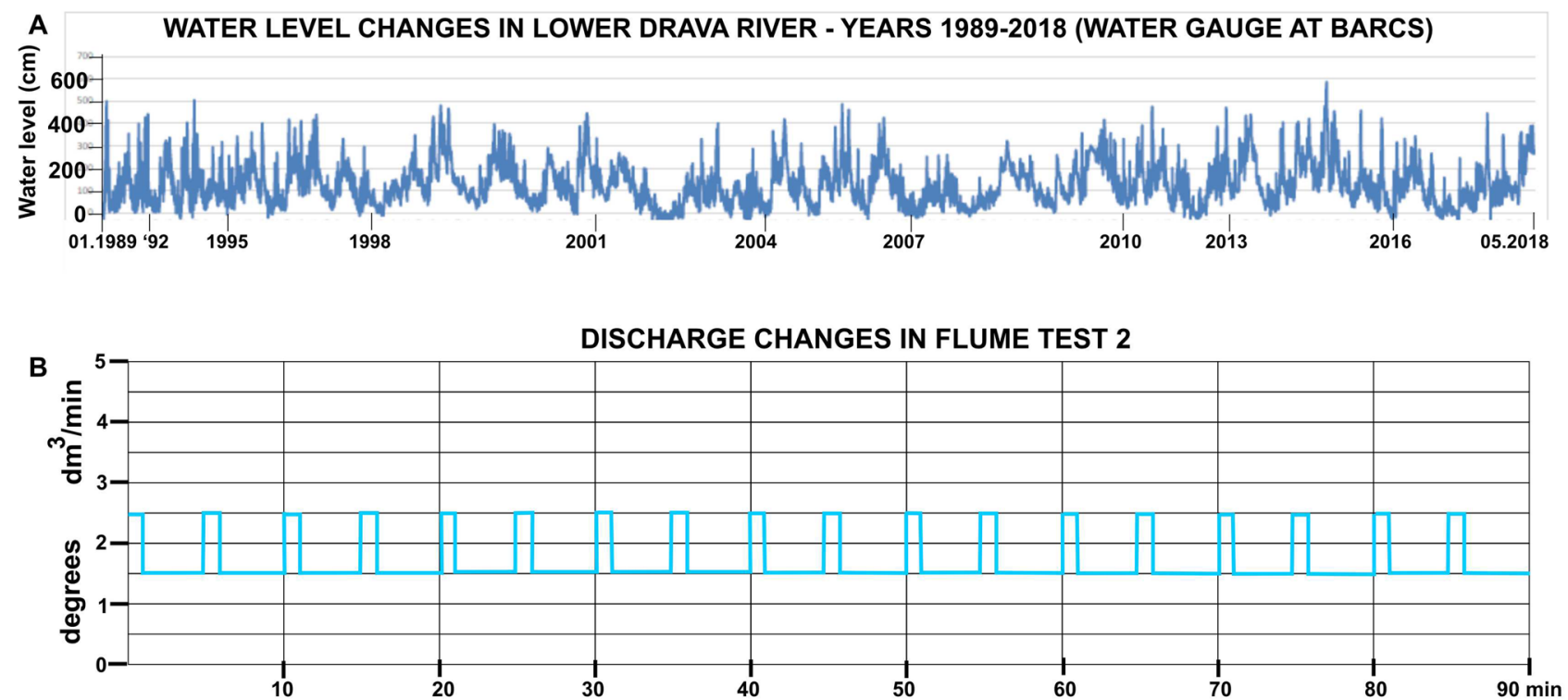

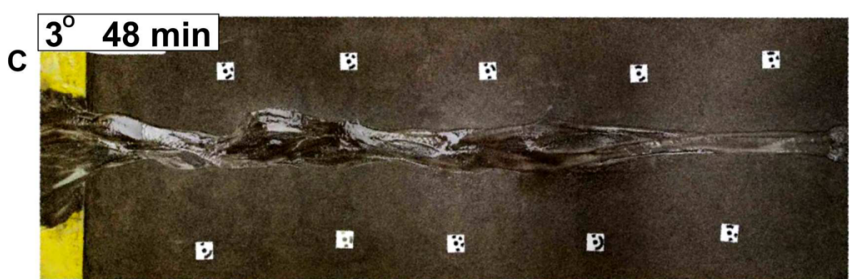

Interpretation

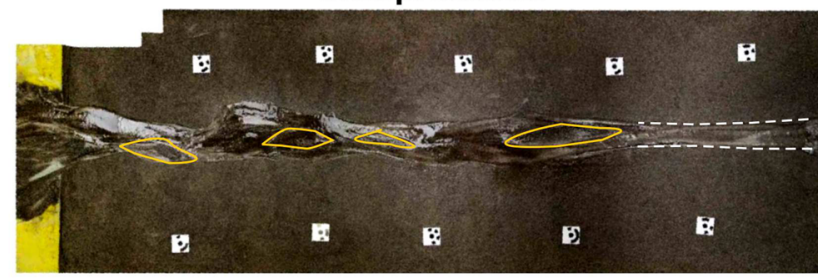

Low flow: channel bars exposed

D

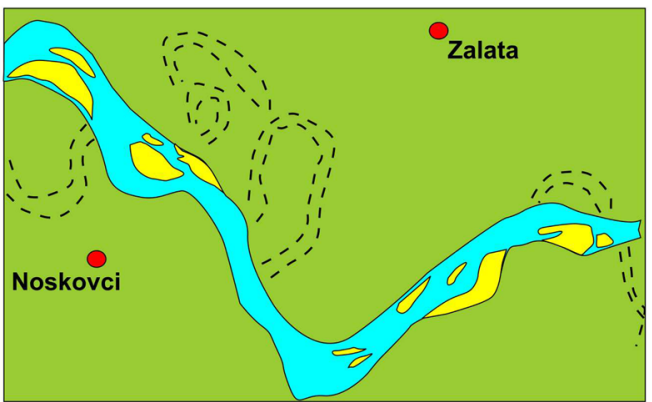

Drava River after channel straightening in the 18th century

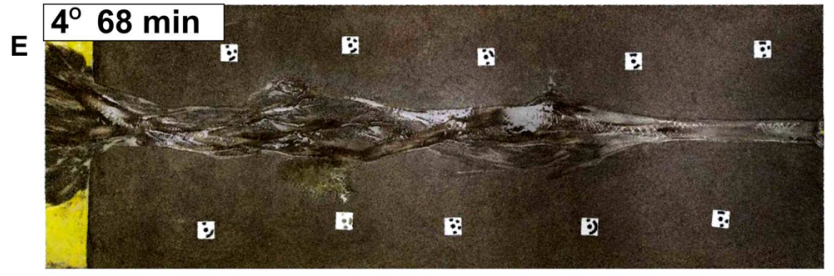

Interpretation

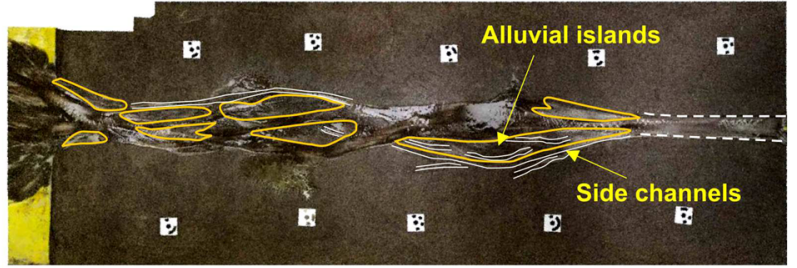

Anabranching planform with one main channel and side channels active at high flows

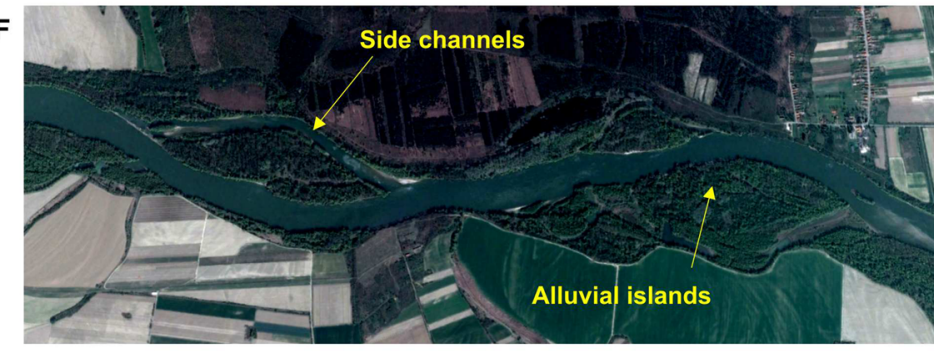

Drava River after dam closure
Fig. 7 Changes in water levels in the lower course of the Drava River (a) and variability of flows simulated in flume test 2 (b). Channel bars formed in an incised channel after 48 min of flume test 2 (c), and barforms in the course of the Drava River (Hungary) in 1816 after channel straightening (d). The planform was redrawn from a historical maps from the second Habsburg military survey available at mapire. eu. e set of channel bars and alluvial islands formed after $68 \mathrm{~min}$ of the experiment, $\mathbf{f}$ anabranching planform of the modern lower Drava River 


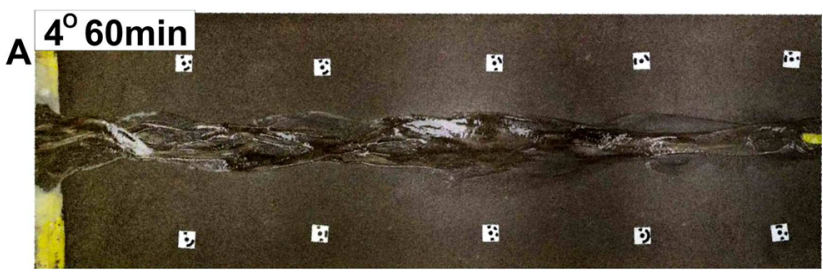

Interpretation
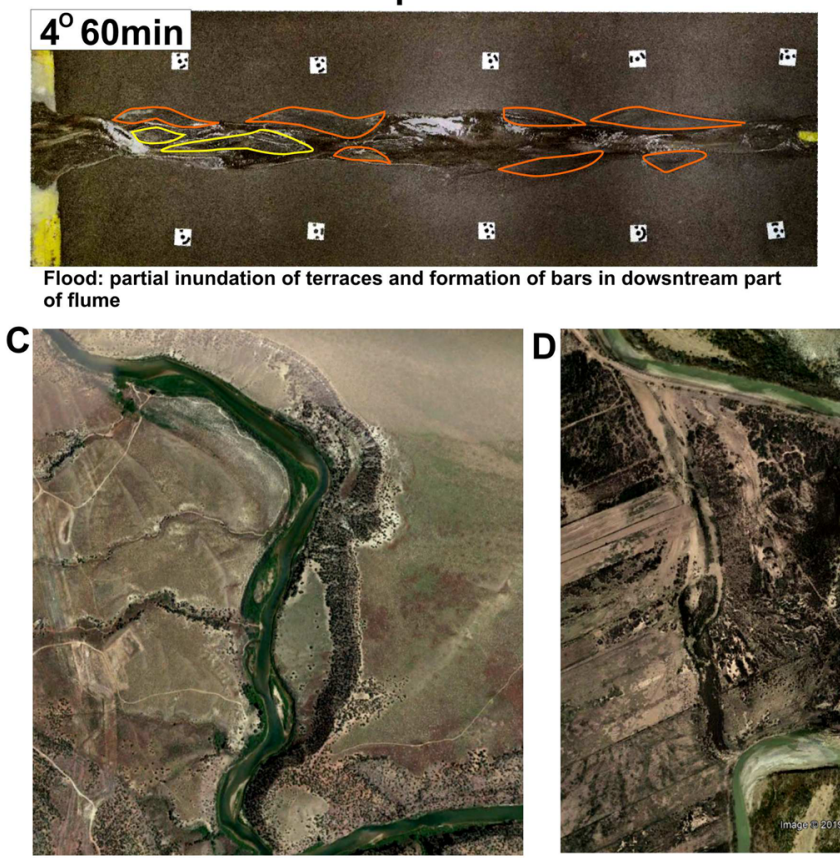

Green River (USA) downstream of dam: sinuous channel with terraces formed along the river channe.

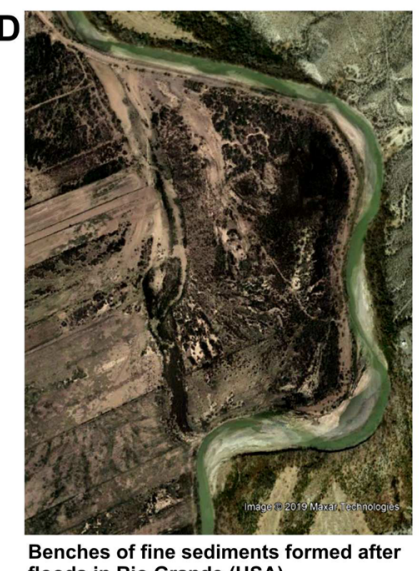

Benches of fine sediments
floods in Rio Grande (USA)

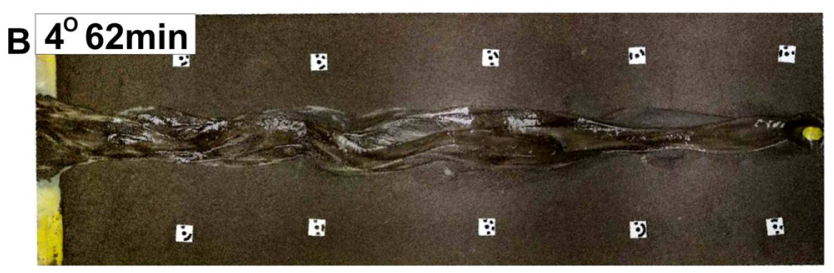

Interpretation

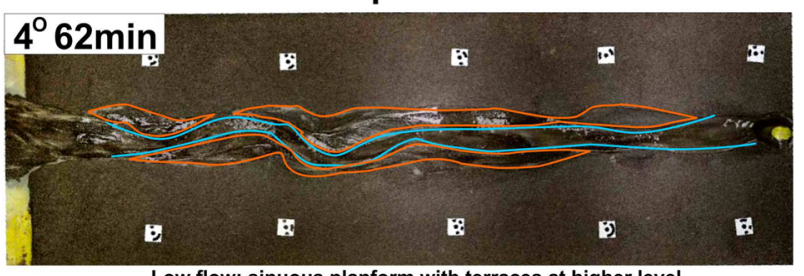

Low flow: sinuous planform with terraces at higher level

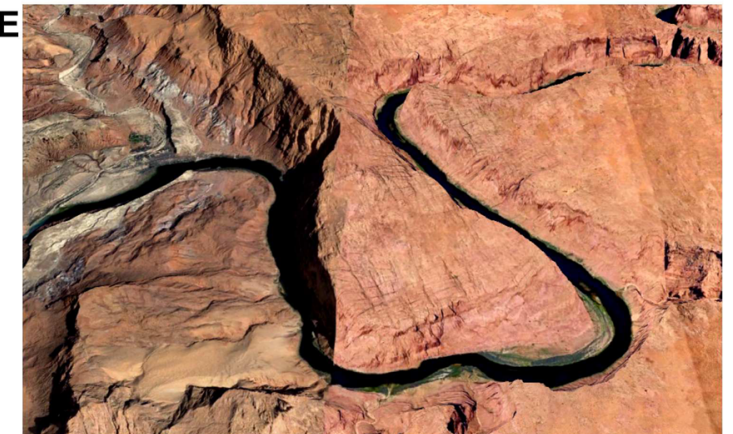

Channel incision and stabilization of sand bars after dam closure in the course of the Colorado River (USA).

Fig. 8 Channel planform in flume test 3 and its similarity to morphodynamics of the Green River (USA) during floods and at low water levels

main difference between the Green River planform and flume test 3 is that the Green River evolves in dominantly depositional conditions (Grams and Schmidt 2005), and the channel in the flume evolved through incision, and downstream transfer of sediments. This downstream transfer commenced through a sequence of depositional and erosional events (terrace formation in periods of low flows and reworking of these terraces by floods causing movement of the material forming these terraces further downstream).

The dynamics of the planform simulated in the flume resembles the course of the Rio Grande (USA) (Fig. 8d). Its channel planform evolves through narrowing interrupted by large controlled floods causing "reset" of channel morphology was observed in the course of the Rio Grande (USA) (Dean and Schmidt 2013). Dean and Schmidt (2013) reported that after such a flood the river bed aggraded and benches built of fine sediments were formed along the banks. The third of conducted flume tests also resembles the course of the Colorado River (USA) downstream of Glen Canyon Dam (cf, Grams et al. 2007). After dam closure, the river bed incised that caused abandonment and stabilization of previously active sandbars (Fig. 8e).

\section{Implications for river restoration}

The conducted experiments reveal the main effects of dam constructions on the evolution of rivers: decrease of discharge (demonstrated in test 1) and elimination of sediment supply (test 2 ). There are very few rivers (simulated by test 3) that can compensate such a loss by supply from floodplain resources or tributaries (e.g., the Green River, USA).

Dam removal seems to be a remediation for rivers affected by the loss of flow simulated in test 1 (Fig. 9). However, the success of such actions depends on a number of factors such as, e.g., dam height, reservoir size, the strategy of dam breaching, amount and grain-size of sediment in a dam reservoir, and rate and grain-size of sediments transported downstream (Foley et al. 2017). Elimination of dams restores the connectivity of sediment transfer and flow (cf. Foley et al. 2017). On the other hand, failure in the strategy of a dam removal brings new hazards and negative consequences, i.e., 


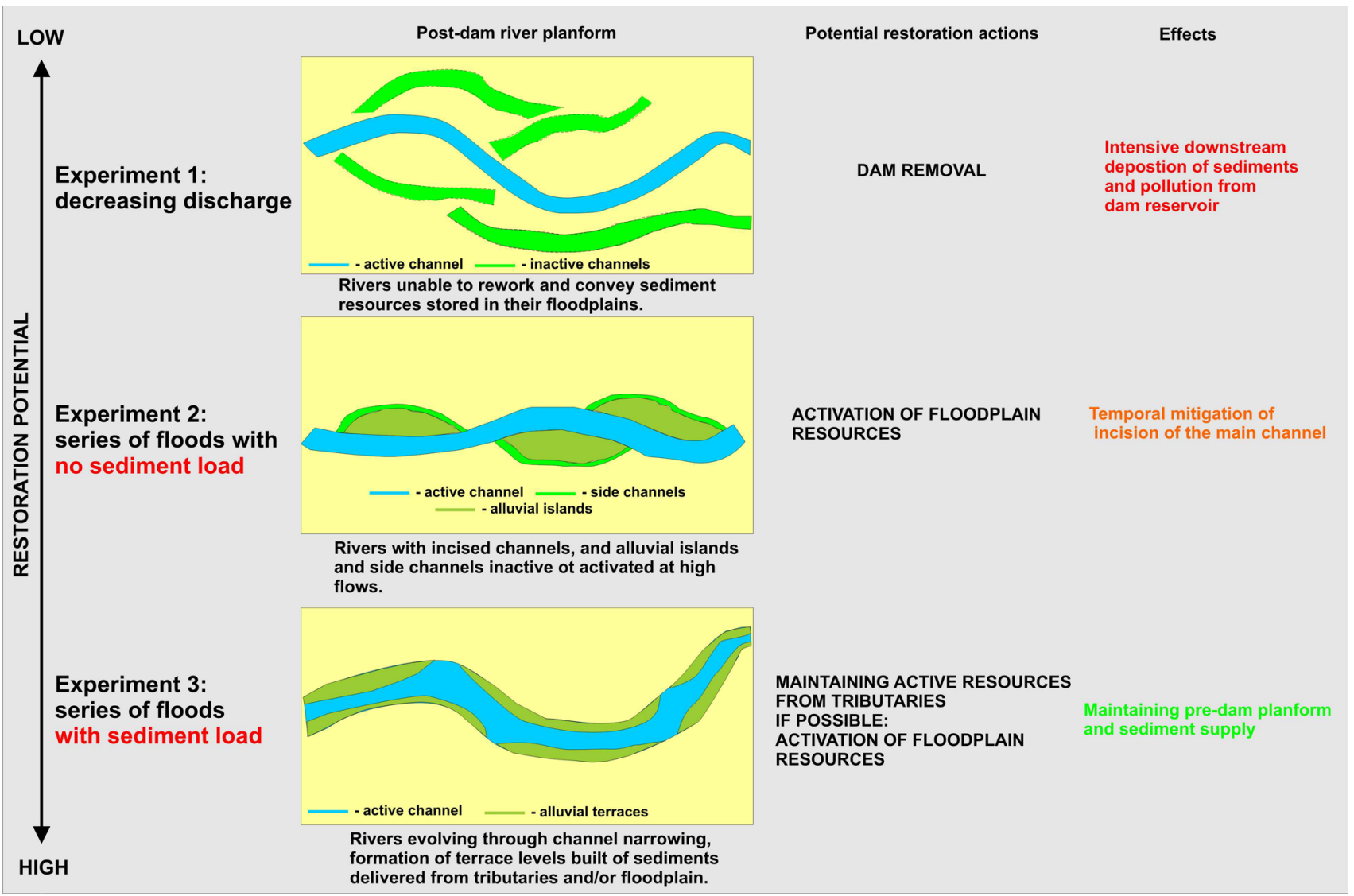

Fig. 9 Types of channel planforms simulated in the flume tests, potential actions and effects of restoration

intensive downstream deposition of sediments and contaminants accumulated in the reservoir. So a restoration through a dam removal should be a result of earlier analysis/tradeoff counting positive and negative effects of such an intervention. One should realize that the new post-restoration system is not synonymous with pre-dam conditions (cf. Foley et al. 2017). Furthermore, local communities are sometimes against such actions, as they perceive the modern landscape of small dams and artificial lakes as a traditional/historical one (the case of New England, USA; Fox et al. 2016). This shows the importance of social aspects as river restoration results in changes in the land use, for instance, from agricultural areas to riverine wetlands. And such a change affects everydays' life and work of local communities.

In the case simulated by test 2 (e.g., the Drava River, Hungary), entraining floodplain resources to complement sediment starvation would be a good solution (Fig. 9). Such a solution would temporally prevent further incision of the main channel and resulting isolation of the side channels. The third of the experiments show that regular delivery of fines helps maintaining a stable planform in periods of low flows, even if the alluvial forms are eroded by high flows. This shows the importance of maintenance of restoring sources of sediment delivery to support a restoration of pre-dam river morphodynamics. In river courses that compensate sediment load caused by dam closure by delivery from tributaries and/or floodplains (Fig. 9) a potential for restoration is the highest. This is possible until this delivery is maintained by protecting the tributary valleys from further hydro-technical works and land use changes.

\section{Conclusions}

Flume experiments were conducted to study the influence of flow reduction, sediment deficit, and series of floods with sediment load on the evolution of channel planform. In conditions of flow reduction (experiment 1 ) the channel planform evolved from braided to single-thread with traces of inactive bifurcating channels. A simulation of series of floods with no sediment load (experiment 2) resulted in the formation of an anabranching planform with side channel active at high flows. The third experiment, in which each of the simulated floods delivered sediment load, allowed for the formation of a single-thread incised channel with terraces 
formed along banks in period of lower flows and reworked by the floods.

The experimental results maintain a number of elements of the evolution of real river courses. Flume test 1 shows behavior of river courses affected by dam closure and constructions of irrigation canals resulting in flow reduction (Central Platte River, USA). Here possibilities for restoration are the lowest owing to significant changes caused not only by dam closure but also other significant land use changes. The anabranching planform formed in flume test 2 resembles sediment-starved rivers downstream of dams, like, e.g., the lower Drava River (Hungary). In this case, going back to pre-dam conditions is impossible. The success of restoration, aiming to maintain the activity of the multi-channel pattern formed after dam closure, depends on availability of sediment and water resources. Flume test 2 also showed that vegetation is not necessary condition to form an anabranching planform. This is confirmed by the presence of real anabranching river in non-vegetated areas (e.g., Rio Capilla, Bolivia). The single-thread planform with terraces obtained in flume test 3 is similar to river courses altered by dams but affected by controlled (or tributary) floods with sediment load (Colorado River, USA; Green River, USA). Here possibilities of potential restoration of river forms and processes are the highest as these rivers compensate the loss of sediments caused by dam constructions with delivery from tributaries and floodplains.

Acknowledgements This study is part of the research project "Processes forming anabranching and meandering rivers: examples of selected rivers from Wielkopolska Lowland and Transdanubia" supported by the National Science Centre, Poland, project No. 2016/23/B/ ST10/01027. We are grateful to Richárd Balogh for his help during the laboratory experiments.

Funding Open Access funding provided by University of Pécs.

Open Access This article is licensed under a Creative Commons Attribution 4.0 International License, which permits use, sharing, adaptation, distribution and reproduction in any medium or format, as long as you give appropriate credit to the original author(s) and the source, provide a link to the Creative Commons licence, and indicate if changes were made. The images or other third party material in this article are included in the article's Creative Commons licence, unless indicated otherwise in a credit line to the material. If material is not included in the article's Creative Commons licence and your intended use is not permitted by statutory regulation or exceeds the permitted use, you will need to obtain permission directly from the copyright holder. To view a copy of this licence, visit http://creativecommons.org/licenses/by/4.0/.

\section{References}

Brauderick CA, Dietrich WE, Leverich GT, Sklar LS (2009) Experimental evidence for the conditions necessary to sustain meandering in coarse-bedded rivers. Proc Natl Acad Sci USA 106:16936-16941
Cutler JS, Olivos JA, Sidlauskas B, Arsimendi I (2020) Habitat loss due to dam development may affect the distribution of marineassociated fishes in Gabon. Afr Ecosphere 11(2):e03024. https:// doi.org/10.1002/ecs2.3024

David M, Labenne A, Carozza J-M, Valette P (2016) Evolutionary trajectory of channel planforms in the middle Garonne River (Toulouse, SW France) over a 130-year period: contribution of mixed multiple factor analysis (MFAmix). Geomorphology 258:21-39

Dean DJ, Schmidt JC (2013) The geomorphic effectiveness of a large flood on the Rio Grande in the Big Bend region: insights on geomorphic controls and post-flood geomorphic response. Geomorphology 201:183-198

Foley MM, Belmore JR, O'Connor JE, Duda JJ, East AE, Grant GE, Anderson CW, Bountry JA, Collins MJ, Connoly PJ, Craig LS, Evans JE, Greene SL, Magilligan FJ, Magirl CS, Major JJ, Pess GR, Randle TJ, Shafroth PB, Torgersen CE, Tullos D, Wilcox AC (2017) Dam removal: listening in. Water Resour Res 53:5229-5246. https://doi.org/10.1002/2017WR020457

Foster JE (1971) History and description of the Mississippi Basin Model. MRM Report 1-6:115-126

Fox CA, Magilligan FJ, Sneddon CS (2016) "You kill the dam, you are killing a part of me": Dam removal and the environmental politics of river restoration. Geoforum 50:73-104

Gierszewski P, Szmańda JB, Luc M (2015) Changes of Vistula River channels pattern caused by Wloclawek Dam functioning based on the analysis of aerial photographs. Przegląd Geograficzny 87(3):517-533

Gierszewski PJ, Habel M, Szmańda J, Luc M (2020) Evaluating effects of dam operation on flow regimes and riverbed adaptation to those changes. Sci Total Environ 710:136202

Grams PE, Schmidt JC (2002) Streamflow regulation and multilevel floodplain formation: channel narrowing on the aggrading Green River in the eastern Uinta Mountains, Colorado and Utah. Geomorphology 44:337-360

Grams PE, Schmidt JC (2005) Equilibrium or indeterminate? Where sediment budgets fail: Sediment mass balance and adjustment of channel form, Green River downstream from Flaming Gorge Dam, Utah and Colorado. Geomorphology 71:156-181

Grams PE, Schmidt JC, Topping DJ (2007) The rate and pattern of bed incision and bank adjustment of the Colorado River in Glen Canyon downstream from Glen Canyon Dam. GSA Bull 119:556-575

Grams PE, Dean DJ, Topping DJ, Walker AE, Schmidt JC (2019) The role of unregulated floods in in maintaining channel complexity in regulated rivers: Case study from the Green River in Canyonlands National Park, Utah. AGU Fall Meeting, 9-13 December 2019, San Francisco, EP51E-2169

Grant GE, Schmidt JC, Lewis SL (2003) A geological framework for interpreting downstream effects of dams on rivers. In: O'Connor JE, Grant GE (eds) A peculiar river. American Geophysical Union, Washington, pp 209-225

Horn JD, Joeckel RM, Fielding CR (2012) Progressive abandonment and planform changes of the central Platter River in Nebraska, central USA, over historical timeframes. Geomorphology 139-140:372-383

Hundey B, Ashmore PE (2009) Length scale of braided river morphology. Water Resour Res. https://doi.org/10.1029/2008WR007521

Kiss T, Balogh M (2015) Characteristics of point-bar development under the influence of a dam: case study of the Drava river at Sigetec, Croatia. J Environ Geogr 8:23-30

Kleinhans MG (2010) Sorting out river channel patterns. Prog Phys Geog 34:287-326

Kleinhans MG, van Dijk WM, van de Lageweg WI, Hoyal DCJD, Markies H, van Maarseveen M, Roosendaal C, van Weesep W, van Breemen D, Hoendervoogt R, Cheshier N (2014) Quantifable 
effectiveness of experimental scaling of river- and delta morphodynamics and stratigraphy. Earth-Sci Rev 133:43-61

Kondolf GM, Rubin ZK, Minear JT (2014) Dams on the Mekong: cumulative sediment starvation. Water Resour Res 50:5158-5169. https://doi.org/10.1002/2013WR014651

Latrubesse EM, Arima EY, Dunne T, Park E, Baker VR, d'Horta FM, Wight C, Wittmann F, Zuanon J, Baker PA, Ribas CC, Norgaard RB, Filizola N, Ansar A, Flyvbjer B, Steveaux JC (2017) Damming the rivers of the Amazon Basin. Nature 546:363-369

Latrubesse EM, d'Horta FM, Ribas CC, Wittmann F, Zuanon J, Park E, Dunne T, Arima EY, Baker PA (2020) Vulnerability of the biota in riverine and seasonally flooded habitata to damming of the Amazon River. Aquat Conserv. https://doi.org/10.1002/aqc.3424

Leduc P, Peirce S, Ashmore P (2019) Short communication: Challenges and applications of structure-from-motion photogrammetry in a physical model of a braided river. Earth Surf Dynam 7:97-106

Leopold LB, Wolman MG (1957) River channel patterns: Braided, meandering and straight, U.S. Geological Survey, Professional Paper 282-B: 1-85

Li Z, Xinyu W, Gao P (2019) Experimental study on the process of neck cutoff and channel adjustment in a highly sinuous meander under constant discharges. Geomorphology 327:215-229

Li J, Bristow CS, Luthi SM, Donselaar ME (2015) Dryland anabranching river morphodynamics: Río Capilla, Salar de Uyuni, Bolivia. Geomorphology 250:282-297

Lóczy D, Czigány S, Pirkhoffer E, Dezső J, Gyenizse P, Halász A (2014) Rehabilitation potential of the Drava River floodplain in Hungary. In: 2nd International Conference Water Resources and Wetlands, Tulcea, Romania.

Métivier F, Lajeunesse E, Devauchelle O (2016) Laboratory rivers: Lacey's law, threshold theory, and channel stability. Earth Surf Dynam 5:187-198

Nanson GC, Knighton AD (1996) Anabranching rivers, their cause, character and classification. Earth Surf Proc Land 21:217-239

Nguyen H, Dargush P, Moss PT, Tran DB (2016) A review of the drivres of 200 years of wetland degradation in the Mekong Delta in Vietnam. Reg Environ Change 16:2303-2315

Nicolas AP, Ashoworth PJ, Sambrook Smith GH, Sandbach SD (2013) Numerical simulation of bar and island morphodynamics in anabranching megarivers. J Geophys Res-Earth 118:1-26. https://doi. org/10.1002/jgrf.20132

Norizan F, Rashid MFA, Roslan NL, Sa'ari R, Ibrahim Z, Mustaffar M, Hezmi MA (2016) Monitoring laboratory scale river channel profile changes using digital close range photogrammetry technique. Malays J Civil Eng 28(Special Issue (3)):252-266. https:// doi.org/10.11113/mjce.v28.16012

Pasha MFK, Yeasmin D, Rentch JW (2015) Dam-lake operation to ptimize fish habitat. Environ Process 2:631-645

Peakall J, Ashworth PJ, Best JL (1996) Physical modelling in fluvial geomorphology: principles, applications and unresolved Issues. In: Rhoads B, Thorn C (eds) The scientific nature of geomorphology edition: proceedings of the 27th Binghamton symposium, chapter 9. Wiley

Petts GE, Gurnell AM (2005) Dams and geomorphology: Research progress and future directions. Geomorphology 71:27-47

Pirkhoffer E, Halmai Á, Czigány S, Bugya T, Rábay A, Bötkös T, Nagy G, Balassa B, Jancskárne Anweiler I, Lóczy D (2014) New opportunities for experiments in fluvial geomorphology: the flume PTETHYS. Hung Geogr Bull 63:425-436

Provansal M, Dufour S, Sabatier F, Anthony EJ, Raccasi G, Robresco S (2014) The geomorphologic evolution and sediment balance of the lower Rhone River (southern France) over the last 130 years: hydropower dams versus other controls. Geomorphology 219:27-41

Rinaldi M (2003) Recent channel adjustments in alluvial rivers of Tuscany, central Italy. Earth Surf Proc Land 28:587-608

Schumm SA, Khan HR (1971) Experimental study of channel patterns. Nature 233:407-409

Schumm SA, Khan HR (1972) Experimental study of channel patterns. GSA Bull 83:1755-1770

Schuurman P, Kleinhans MG (2015) Bar dynamics and bifurcation evolution in a modelled braided sand-bed river. Earth Surf Proc Land 40:1318-1333

Słowik M (2018) The formation of an anabranching planform in a sandy floodplain by increased flows and sediment load. Earth Surf Proc Land 43:623-638

Słowik M, Dezső J, Marciniak A, Tóth G, Kovács J (2018) Evolution of river planforms downstream of dams: effect of dam construction or earlier human-induced changes? Earth Surf Proc Land 43:2045-2063

Struiksma N, Olesen KW, Flokstra C, De Vriend JH (1985) Bed deformation in curved alluvial channels. J Hydraul Res 23:57-79

Surian N (1999) Channel changes due to river regulation: the case of the Piave River, Italy. Earth Surf Process Land 24(12):1135-1151

Surian N, Rinaldi M (2003) Morphological response to river engineering and management in alluvial channels in Italy. Geomorphology 50:307-326

Surian N, Zillani N, Comiti F, Lenzi MA, Mao L (2009) Channel adjustments and alteration of sediment fluxes in gravel-bed rivers of North-Eastern Italy: potentials and limitations for channel recovery. River Res Appl 25:551-567

Syvitsky JPM, Kettner M (2011) Sediment flux and the Anthropocene. Phi Trans R Soc A 369:957-975

Tal M, Paola C (2007) Dynamic single-thread channels maintained by the interaction of flow and vegetation. Geology 35:347-350

Van de Lageweg WI, van Dijk WM, Kleinhans MG (2013) Channel belt architecture formed by a meandering river. Sedimentology 60:840-859

Van de Lageweg WI, van Dijk WM, Box D, Kleinhans MG (2016) Archimetrics: a quantitative tool to predict three-dimensional meander belt sandbody heterogeneity. Depos Rec 2:22-46

van Dijk WM, van de Lageweg WI, Kleinhans MG (2012) Experimental meandering river with chute cutoffs. J Geophys Res-Earth. https://doi.org/10.1029/2011JF002314

van Dijk WM, van de Lageweg WI, Kleinhans MG (2013) Formation of a cohesive floodplain in a dynamic experimental meandering river. Earth Surf Proc Land 38:1550-1565

Weisscher SAH, Shimizu Y, Kleinhans MG (2019) Upstream perturbation and floodplain formation effects on chute-cutoff-dominated meandering river pattern and dynamics. Earth Surf Proc Land 44:2156-2169

Williams GP, Wolman MG (1984) Downstream effects of dams on alluvial rivers. Geol Surv Prof Pap 1286:1-83

Yang H, Lin B, Sun J, Huang G (2017) Simulating laboratory braided rivers with bed-load sediment transport. Water 9:686. https://doi. org/10.3390/w9090686

Publisher's Note Springer Nature remains neutral with regard to jurisdictional claims in published maps and institutional affiliations. 